(c) American Dairy Science Association, 2006.

\title{
Effect of Safflower Oil, Flaxseed Oil, Monensin, and Vitamin E on Concentration of Conjugated Linoleic Acid in Bovine Milk Fat
}

\author{
J. A. Bell, ${ }^{\star}$ J. M. Griinari,† and J. J. Kennelly ${ }^{\star 1}$ \\ *Department of Agricultural, Food and Nutritional Science, University of Alberta, Edmonton, AB, Canada T6G 2P5 \\ †Department of Animal Science, University of Helsinki, 00014 Finland
}

\begin{abstract}
Conjugated linoleic acid (CLA) refers to a mixture of conjugated octadecadienoic acids of predominantly ruminant origin. The main isomer in bovine milk fat is the cis-9, trans-11 CLA. Interest in CLA increased after the discovery of its health-promoting properties, including potent anticarcinogenic activity. Two experiments were conducted to evaluate dietary strategies aimed at increasing the concentration of CLA in bovine milk fat. Both experiments were organized as a randomized complete block design with a repeated measures treatment structure. In Experiment 1, 28 Holstein cows received either a control diet or one of 3 treatments for a period of $2 \mathrm{wk}$. The control diet consisted of $60 \%$ forage (barley silage, alfalfa silage, and alfalfa hay) and $40 \%$ concentrate on a dry matter (DM) basis, fed as a total mixed ration (TMR). The concentrate was partially replaced in the treatment groups with $24 \mathrm{ppm}$ of monensin (MON), 6\% of DM safflower oil (SAFF), or 6\% of DM safflower oil plus $24 \mathrm{ppm}$ of monensin (SAFF/M). Average cis-9, trans-11 CLA levels in milk fat after 2 wk of feeding were $0.45,0.52,3.36$, and $5.15 \%$ of total fatty acids for control, MON, SAFF, and SAFF/M, respectively. In Experiment 2, 62 Holstein cows received either a control diet or one of 5 treatment diets for a period of $9 \mathrm{wk}$. The control diet consisted of $60 \%$ forage (barley silage, alfalfa silage, and alfalfa hay) and $40 \%$ concentrate on a DM basis, fed as a TMR. The concentrate was partially replaced in the treatment groups with $6 \%$ of DM safflower oil (SAFF), $6 \%$ of DM safflower oil plus $150 \mathrm{IU}$ of vitamin $\mathrm{E} / \mathrm{kg}$ of $\mathrm{DM}(\mathrm{SAFF} / \mathrm{E}), 6 \%$ of DM safflower oil plus $24 \mathrm{ppm}$ of monensin (SAFF/M), $6 \%$ of DM safflower oil plus $24 \mathrm{ppm}$ of monensin plus $150 \mathrm{IU}$ of vitamin $\mathrm{E} / \mathrm{kg}$ of DM (SAFF/ME), or $6 \%$ of DM flaxseed oil plus 150 IU of vitamin E/kg of DM (FLAX/ E). Average cis-9, trans-11 CLA levels during the treatment period were $0.68,4.12,3.48,4.55,4.75$, and $2.80 \%$ of total fatty acids for control, SAFF, SAFF/E, SAFF/
\end{abstract}

Received December 28, 2004.

Accepted August 23, 2005.

${ }^{1}$ Corresponding author: john.kennelly@ualberta.ca
$\mathrm{M}, \mathrm{SAFF} / \mathrm{ME}$, and FLAX/E, respectively. The combination of safflower oil with monensin was particularly effective at increasing milk fat CLA. The addition of vitamin $\mathrm{E}$ to the diet partially prevented the depression in milk fat associated with oilseed feeding, but had no significant effect on the concentration of CLA in milk. Key words: conjugated linoleic acid, bovine milk fat, safflower, flaxseed

\section{INTRODUCTION}

Conjugated linoleic acid (CLA) is the term given to a mixture of conjugated octadecadienoic acids of predominantly ruminant origin. The conjugated doublebond configuration can be found on a range of positions on the carbon chain; each double bond has either a cis or trans orientation. The predominant isomer in bovine milk fat is the cis-9, trans-11 CLA, which accounts for $>82 \%$ of the total (Chin et al., 1992). Although the presence of CLA in milk has been known for a long time (Parodi, 1999), current interest in this fatty acid (FA) has come from the more recent discovery of its anticarcinogenic properties (Pariza and Hargraves, 1985). Although the effects have mostly been demonstrated in animal models, it is anticipated that CLA will have similar beneficial effects in humans. As CLA is primarily a product of ruminant animals, meat and milk from ruminants provides the best natural source of CLA in the human diet (Chin et al., 1992).

The CLA found in ruminant meat and milk appears to originate either directly from the rumen or by tissue desaturation of rumen-derived trans-11 18:1. In the rumen, isomers of CLA and trans 18:1 are produced as intermediates in the biohydrogenation of unsaturated FA (Kepler et al., 1966). It has been suggested that little cis-9, trans-11 CLA actually accumulates in the rumen and that the majority of milk CLA is derived from trans-11 18:1 in the mammary gland through the action of $\Delta^{9}$-desaturase (Griinari et al., 2000). Therefore, factors that increase the level of trans-11 18:1 synthesized in the rumen would be expected to increase milk CLA.

Diet is by far the most influential factor determining the concentration of CLA in bovine milk fat (Griinari 
and Bauman 1999; Chilliard et al. 2000). The objective of this study was to evaluate the effect of various combinations of safflower oil, flaxseed oil, monensin, and vitamin $\mathrm{E}$ on the concentration of CLA in the bovine milk. Safflower oil and flaxseed oil were chosen for their high content of cis-9, cis-12 18:2 and cis-9, cis-12, cis-15 18:3, respectively. Monensin and vitamin E, although not adding substrates for CLA or trans-11 18:1 production, were chosen for their potential effect on the biohydrogenation process. Fellner et al. (1997) studied the effects of ionophores on lipid biohydrogenation using a continuous culture system. They found that the antiporter ionophores monensin, nigericin, and tetronasin interfered with the biohydrogenation of cis-9, cis-12 18:2. The study showed that ionophores caused a reduction in the extent of $c i s-9, c i s-12$ 18:2 biohydrogenation with an accumulation of intermediate products, including CLA. They followed up this work in dairy cows by evaluating the effect of monensin at $24 \mathrm{mg} / \mathrm{kg}$ of dietary DM on milk CLA over a 28-d period (Sauer et al., 1998). They observed a small but significant increase in CLA from 0.8 to $1.3 \%$ of milk fat. Other studies have failed to show a benefit of ionophores for enriching the concentration of CLA in milk fat (Chouinard et al., 1998; Dhiman et al., 1999). Therfore, the usefulness of ionophores to enhance milk CLA is considered equivocal. Previous researchers have shown that dietary vitamin $\mathrm{E}$ was capable of reducing the extent of diet-induced milk fat depression (Charmley and Nicholson, 1993, 1994; Focant et al., 1998). Milk fat depression is associated with a shift in rumen biohydrogenation, characterized by increased formation of trans-10 18:1 (Bauman and Griinari, 2001). Thus, it is possible that the alleviation of this depression by vitamin $\mathrm{E}$ is brought about by a shift in rumen biohydrogenation toward pathways that produce trans-11 18:1 and away from trans-10 18:1. Apart from increased milk fat percentage, this could also provide more trans-11 18:1 for mammary CLA synthesis.

\section{MATERIALS AND METHODS}

Two sequential experiments were carried out to determine the effect of safflower oil, flaxseed oil, monensin, and vitamin $\mathrm{E}$ on the CLA concentration of milk fat. All procedures involving the use of animals were approved by the Faculty Animal Policy and Welfare Committee at the University of Alberta.

\section{Experiment 1}

Animals and Treatments. Twenty-eight lactating Holstein cows (8 primiparous, 20 multiparous) were used in a randomized complete block design with re- peated measures. The animals averaged $213 \pm 61 \mathrm{DIM}$ at the start of the trial with an average BW of $607 \pm$ $57.8 \mathrm{~kg}$ and an average BCS of $2.77 \pm 0.46$ (5-point scale). All cows were first fed a control diet for $8 \mathrm{~d}$ (wk 0 ). Animals were then blocked according to parity and DIM and randomly placed into one of 4 groups. Each group was fed one of 4 diets for a 15-d treatment period: 1) control diet; 2) control diet including monensin supplemented at $24 \mathrm{ppm}$ of DM (MON); 3) control diet including safflower oil supplemented at $6 \%$ of DM (SAFF); 4) control diet including safflower oil supplemented at $6 \%$ of DM plus monensin supplemented at 24 $\mathrm{ppm}$ of DM (SAFF/M). The supplementary ingredients were added to their respective concentrates prior to addition of forages by thorough mixing in Calan data rangers in 500-kg batches. All diets were formulated to meet or exceed NRC (1989) recommendations.

Cows were housed in tie stalls, and water was available at all times. The diets were fed once per day at $0900 \mathrm{~h}$ as a TMR consisting of $60 \%$ forage and $40 \%$ concentrate (Table 1). Feed intake was recorded daily and adjusted to maintain 5 to $10 \%$ orts. Milking was carried out twice per day starting at 0330 and $1430 \mathrm{~h}$. Milk yield was recorded daily.

Sampling and Analysis of Feed and Milk. Samples of TMR, orts, and ingredients were taken twice weekly. Each sample was immediately dried at $60^{\circ} \mathrm{C}$ for $72 \mathrm{~h}$. Prior to analysis, samples were ground to pass through a 1-mm screen using a model 4 Thomas-Wiley Laboratory Mill (Arthur H. Thomas Co., Philadelphia, PA). True DM was determined by drying samples to a constant weight at $110^{\circ} \mathrm{C}$ true $\mathrm{DM}=(\mathrm{DM}$ percentage after $\left.60^{\circ} \mathrm{C}\right) \times\left(\mathrm{DM}\right.$ percentage after $\left.\left.110^{\circ} \mathrm{C}\right) / 100\right]$. Following drying at $110^{\circ} \mathrm{C}$, ash content was determined by ashing at $500^{\circ} \mathrm{C}$ for at least $8 \mathrm{~h}$. Samples were also analyzed for CP (Leco Corporation, St. Joseph, MI), NDF and ADF (Van Soest et al., 1991), and crude fat (Elliot et al., 1999).

Milk was sampled from each cow at a.m. and p.m. milkings on the last $2 \mathrm{~d}$ of wk 0 and the last $2 \mathrm{~d}$ of the treatment period. The amount sampled at each milking was proportional to the milk yield. The a.m. and p.m. samples were then combined to give one sample for each cow on each sampling day. A portion of milk from each cow was preserved with potassium dichromate and analyzed for protein, fat, lactose, and SCC using near infrared spectroscopy (AOAC, 1996; method 972.16) at the Alberta Agriculture, Food and Rural Development Central Milk Testing Laboratory (Edmonton, Alberta, Canada). The rest of the milk was stored at $-20^{\circ} \mathrm{C}$ for later analysis.

Lipids for FA analysis were extracted from the milk using chloroform:methanol (2:1; Folch et al., 1957). The milk was thawed at $27^{\circ} \mathrm{C}$. A $2-\mathrm{mL}$ sample of the thawed 
Table 1. Ingredient and chemical composition of diets (Experiment 1)

\begin{tabular}{|c|c|c|c|c|}
\hline \multirow[b]{2}{*}{ Item } & \multicolumn{4}{|c|}{$\operatorname{Diet}^{1}$} \\
\hline & CTL & MON & SAFF & $\mathrm{SAFF} / \mathrm{M}$ \\
\hline & & $-(\%$ & DM) & \\
\hline \multicolumn{5}{|l|}{ Ingredient composition } \\
\hline Barley silage & 25 & 25 & 25 & 25 \\
\hline Alfalfa silage & 25 & 25 & 25 & 25 \\
\hline Alfalfa hay & 10 & 10 & 10 & 10 \\
\hline Ground corn & 20.5 & 20 & 13 & 12.5 \\
\hline Barley & 10.4 & 10.4 & 10.4 & 10.4 \\
\hline Soybean meal & 7 & 7 & 8.5 & 8.5 \\
\hline Safflower oil ${ }^{2}$ & 0 & 0 & 6 & 6 \\
\hline Monensin ${ }^{3}$ & 0 & 0.54 & 0 & 0.54 \\
\hline Limestone & 0.6 & 0.6 & 0.6 & 0.6 \\
\hline Mineral salt ${ }^{4}$ & 0.4 & 0.4 & 0.4 & 0.4 \\
\hline Dicalcium phosphate & 0.40 & 0.40 & 0.40 & 0.40 \\
\hline Magnesium oxide & 0.28 & 0.28 & 0.28 & 0.28 \\
\hline Salt & 0.2 & 0.16 & 0.2 & 0.16 \\
\hline Sodium bicarbonate & 0.15 & 0.15 & 0.15 & 0.15 \\
\hline Vitamins $\mathrm{A}, \mathrm{D}$, and $\mathrm{E}^{5}$ & 0.07 & 0.07 & 0.07 & 0.07 \\
\hline \multicolumn{5}{|l|}{ Chemical composition } \\
\hline DM, \% & 44.7 & 44.7 & 45.2 & 45.8 \\
\hline $\mathrm{CP}$ & 17.3 & 17.3 & 17.0 & 16.9 \\
\hline Crude fat & 4.34 & 4.51 & 7.74 & 7.58 \\
\hline $\mathrm{NDF}$ & 44.1 & 45.1 & 46.7 & 48.0 \\
\hline $\mathrm{ADF}$ & 24.8 & 26.6 & 27.9 & 27.9 \\
\hline Ash & 10.3 & 10.4 & 9.9 & 10.1 \\
\hline $\mathrm{NE}_{\mathrm{L}},{ }^{6} \mathrm{Mcal} / \mathrm{kg}$ & 1.60 & 1.59 & 1.83 & 1.82 \\
\hline
\end{tabular}

${ }^{1}$ Diets: Control (CTL) and control supplemented with monensin (MON), safflower oil (SAFF), safflower oil plus monensin (SAFF/M).

${ }^{2}$ Contained 18:2 n-6 (75.9\%), 18:1 n-9 (12.5\%), 18:0 (1.9\%), and 16:0 $(7.0 \%)$.

${ }^{3}$ Contained 4,400 mg of Rumensin (Elanco Animal Health, ON, Canada) $/ \mathrm{kg}$.

${ }^{4}$ Contained salt (minimum, $\left.95 \%\right)$, iodine $(150 \mathrm{mg} / \mathrm{kg})$, cobalt $(50$ $\mathrm{mg} / \mathrm{kg})$, copper $(3500 \mathrm{mg} / \mathrm{kg})$, manganese $(10,000 \mathrm{mg} / \mathrm{kg})$, zinc $(9000$ $\mathrm{mg} / \mathrm{kg})$, and selenium $(75 \mathrm{mg} / \mathrm{kg}$ ).

${ }^{5}$ Contained vitamin A (minimum, $10,000,000 \mathrm{IU} / \mathrm{kg}$ ), vitamin D (minimum, 1,000,000 IU/kg), and vitamin $\mathrm{E}$ (minimum 10,000 IU/ $\mathrm{kg})$.

${ }^{6}$ Estimated from NRC (1989).

milk was placed in a 50-mL tube. Twenty-four milliliters of chloroform:methanol (2:1) was added. The tube was capped, shaken for $30 \mathrm{~s}$ by hand, and allowed to stand for at least $1 \mathrm{~h}$. Eight milliliters of $0.8 \% \mathrm{NaCl}$ (wt/vol) was added, and the tube stood overnight at $4^{\circ} \mathrm{C}$. The tube was then warmed to room temperature and centrifuged at approximately $1,500 \times g$ for $5 \mathrm{~min}$. The upper methanol:water layer was removed using a water aspirator and discarded. Ten milliliters of the lower chloroform phase was transferred to a 20 -mL glass scintillation vial. The chloroform was evaporated at $40^{\circ} \mathrm{C}$ under nitrogen leaving the fat ( $\sim 20$ to $30 \mathrm{mg})$.

The FA were then methylated by sodium methoxide using a procedure similar to that described by Chouinard et al. (1999), which was based on the method of Christie (1982). Two milliliters of hexane was added to the $20-\mathrm{mL}$ glass scintillation vial to resolubilize the fat.
From this, a volume representing approximately $5 \mathrm{mg}$ of fat was removed and placed in a 14-mL screw-top test tube. Twenty microliters of methyl acetate was added. Following vortexing, $40 \mu \mathrm{L}$ of methylating agent ( $0.5 \mathrm{M}$ sodium methoxide) was added. The mixture was vortexed and allowed to react for $10 \mathrm{~min}$ at room temperature. The reaction was stopped with $30 \mu \mathrm{L}$ of termination reagent $(1 \mathrm{~g}$ of oxalic acid in $30 \mathrm{~mL}$ of diethyl ether). The sample was then centrifuged at $2,400 \times g$ for $5 \mathrm{~min}$, leaving a clear layer of hexane from which an aliquot was taken for gas chromatography analysis.

The FA methyl esters (FAME) were analyzed on a Varian 3600 gas chromatograph (Varian Chromatography Systems, Walnut Creek, CA) with a temperatureprogrammable injector and flame-ionization detector. Separation of the FAME was performed using a CP-Sil 88 fused silica capillary column [50 $\mathrm{m} \times 0.25 \mathrm{~mm}$ (i.d.) with $0.25-\mu \mathrm{m}$ film thickness] (Chrompack, Middelburg, The Netherlands). Purified Helium (Praxair, Edmonton, Canada) was used as the carrier gas with a head pressure of $25 \mathrm{psi}$ and a flow rate of $1 \mathrm{~mL} / \mathrm{min}$. The initial column temperature was set at $50^{\circ} \mathrm{C}$ and held for $0.1 \mathrm{~min}$, increased to $180^{\circ} \mathrm{C}$ at $25^{\circ} \mathrm{C} / \mathrm{min}$ and held for $1 \mathrm{~min}$, further increased to $190^{\circ} \mathrm{C}$ at $2^{\circ} \mathrm{C} / \mathrm{min}$ and held for $2 \mathrm{~min}$, and finally increased to $230^{\circ} \mathrm{C}$ at $10^{\circ} \mathrm{C} /$ min and held for $7 \mathrm{~min}$. The initial injector temperature was $90^{\circ} \mathrm{C}$, increasing at $150^{\circ} \mathrm{C} / \mathrm{min}$ to $240^{\circ} \mathrm{C}$ and held for $23 \mathrm{~min}$. The detector temperature was set at $240^{\circ} \mathrm{C}$. Peak area was measured using the Shimadzu ClassVP chromatography data system (Shimadzu Scientific Instruments Inc., Columbia, MD). Peaks were identified using Nu-Chek Prep standards \#85 and \#411. Conjugated linoleic acid isomers were identified using standards from Matreya (Matreya, Inc., PA). Detector response for individual FA was verified using $\mathrm{Nu}$-Chek Prep standard \#60 (Nu Chek Prep). Each FA was reported as a percentage of FAME.

\section{Experiment 2}

Animals and Treatments. Sixty-two (28 primiparous, 34 multiparous) lactating Holstein cows were used in a randomized complete block design with repeated measures. Animals were blocked according to parity and DIM. Cows within each block were then randomly assigned to one of 6 diets (10 or 11 cows per diet): 1 ) control diet, 2) SAFF, 3) SAFF/E, 4) SAFF/M; 5) control diet including safflower oil at $6 \%$ of DM plus monensin at $24 \mathrm{ppm}$ of $\mathrm{DM}$ plus vitamin $\mathrm{E}$ at $150 \mathrm{IU} / \mathrm{kg}$ of DM (SAFF/ME), and 6) control diet including flaxseed oil at $6 \%$ of DM plus vitamin E at $150 \mathrm{IU} / \mathrm{kg}$ of DM (FLAX/ E). The supplementary ingredients were added to their respective concentrates prior to addition of forages by thorough mixing in Calan data rangers in $500-\mathrm{kg}$ 
BELL ET AL.

Table 2. Ingredient and chemical composition of diets (Experiment 2)

\begin{tabular}{|c|c|c|c|c|c|c|}
\hline \multirow[b]{2}{*}{ Item } & \multicolumn{6}{|c|}{ Diet $^{1}$} \\
\hline & CTL & SAFF & $\mathrm{SAFF} / \mathrm{E}$ & $\mathrm{SAFF} / \mathrm{M}$ & $\mathrm{SAFF} / \mathrm{M} / \mathrm{E}$ & FLAX/E \\
\hline & & & 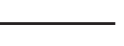 & f DM) & & . \\
\hline \multicolumn{7}{|l|}{ Ingredient composition } \\
\hline Barley silage & 26.30 & 26.29 & 26.28 & 26.30 & 26.29 & 26.28 \\
\hline Alfalfa silage & 21.20 & 21.19 & 21.19 & 21.20 & 21.19 & 21.19 \\
\hline Alfalfa hay & 12.50 & 12.49 & 12.49 & 12.50 & 12.49 & 12.49 \\
\hline Ground corn & 14.70 & 12.99 & 12.99 & 12.50 & 12.04 & 12.99 \\
\hline Barley & 14.44 & 9.58 & 9.29 & 9.50 & 9.40 & 9.29 \\
\hline Safflower oil ${ }^{2}$ & 0 & 6.00 & 6.00 & 6.00 & 6.00 & 0 \\
\hline Flaxseed oil ${ }^{3}$ & 0 & 0 & 0 & 0 & 0 & 6.00 \\
\hline Soybean meal & 5.00 & 5.00 & 5.00 & 5.00 & 5.20 & 5.00 \\
\hline Canola meal & 0 & 2.00 & 2.00 & 2.00 & 2.00 & 2.00 \\
\hline Corn gluten meal & 2.00 & 2.00 & 2.00 & 2.00 & 2.00 & 2.00 \\
\hline Animal fat & 1.50 & 0 & 0 & 0 & 0.10 & 0 \\
\hline Limestone & 0.60 & 0.60 & 0.60 & 0.60 & 0.60 & 0.60 \\
\hline Dicalcium phosphate & 0.55 & 0.65 & 0.65 & 0.65 & 0.65 & 0.65 \\
\hline Mineral salt ${ }^{4}$ & 0.40 & 0.40 & 0.40 & 0.40 & 0.40 & 0.40 \\
\hline Salt & 0.30 & 0.30 & 0.30 & 0.30 & 0.30 & 0.30 \\
\hline Magnesium oxide & 0.28 & 0.28 & 0.28 & 0.28 & 0.28 & 0.28 \\
\hline Sodium bicarbonate & 0.15 & 0.15 & 0.15 & 0.15 & 0.15 & 0.15 \\
\hline Vitamins $\mathrm{A}, \mathrm{D}$, and $\mathrm{E}^{5}$ & 0.08 & 0.08 & 0.08 & 0.08 & 0.08 & 0.08 \\
\hline Monensin ${ }^{6}$ & 0 & 0 & 0 & 0.54 & 0.54 & 0 \\
\hline Vitamin $\mathrm{E}^{7}$ & 0 & 0 & 0.30 & 0 & 0.30 & 0.30 \\
\hline \multicolumn{7}{|l|}{ Chemical composition } \\
\hline $\mathrm{DM}, \%$ & 43.9 & 44.1 & 44.0 & 43.8 & 43.5 & 44.4 \\
\hline $\mathrm{CP}$ & 17.2 & 16.7 & 17.0 & 16.9 & 16.9 & 17.5 \\
\hline Crude fat & 6.50 & 10.49 & 9.04 & 9.02 & 8.89 & 9.78 \\
\hline NDF & 43.7 & 43.8 & 45.2 & 46.7 & 46.3 & 45.3 \\
\hline $\mathrm{ADF}$ & 26.8 & 28.3 & 28.5 & 28.9 & 28.8 & 27.9 \\
\hline Ash & 10.3 & 10.2 & 10.0 & 10.1 & 10.4 & 10.1 \\
\hline $\mathrm{NE}_{\mathrm{L}},{ }^{8} \mathrm{Mcal} / \mathrm{kg}$ & 1.71 & 1.88 & 1.87 & 1.87 & 1.87 & 1.87 \\
\hline
\end{tabular}

${ }^{1}$ Diets were control (CTL) and control supplemented with, safflower oil (SAFF), safflower oil plus vitamin $\mathrm{E}$ (SAFF/E), safflower oil plus monensin (SAFF/M), safflower oil plus monensin plus vitamin E (SAFF/ME), or flaxseed plus vitamin E (FLAX/E).

${ }^{2}$ Contained 18:2 n-6 (76.0\%), 18:1 n-9 (14.8\%), 18:0 (2.3\%), and 16:0 (6.7\%).

${ }^{3}$ Contained 18:3 n-3 (41.7\%), 18:2 n-6 (21.3\%), 18:1 n-9 (23.1\%), 18:0 (4.0\%), and 16:0 (5.6\%).

${ }^{4}$ Contained salt (minimum, $95 \%$ ), iodine $(150 \mathrm{mg} / \mathrm{kg})$, cobalt $(50 \mathrm{mg} / \mathrm{kg})$, copper $(3,500 \mathrm{mg} / \mathrm{kg})$, manganese $(10,000 \mathrm{mg} / \mathrm{kg})$, zinc $(9,000 \mathrm{mg} / \mathrm{kg})$, and selenium $(75 \mathrm{mg} / \mathrm{kg})$.

${ }^{5}$ Contained vitamin A (minimum, 10,000,000 IU/kg), vitamin D (minimum, 1,000,000 IU/kg), and vitamin $\mathrm{E}$ (minimum, 10,000 IU/kg).

${ }^{6}$ Contained 4,400 mg of Rumensin (Elanco Animal Health, ON, Canada)/kg.

${ }^{7}$ Contained 50,000 mg of vitamin E/kg.

${ }^{8}$ Estimated from NRC (1989).

batches. All diets were formulated to meet or exceed NRC (1989) recommendations.

Cows were housed in tie stalls, and water was available at all times. The diets were fed once per day at $0900 \mathrm{~h}$ as a TMR consisting of $60 \%$ forage and $40 \%$ concentrate (Table 2). Feed intake was recorded daily and adjusted to maintain 5 to $10 \%$ orts. The control diet was fed initially to all cows for $10 \mathrm{~d}$ (wk 0). Cows then received their respective diets for a period of $9 \mathrm{wk}$. Cows were adapted to dietary change over a 3-d period. Milking was carried out twice daily starting at 0330 and $1430 \mathrm{~h}$. Milk yield was recorded daily. Body weight was recorded once per week after a.m. milking, and
BCS was estimated on a 5-point scale at the end of wk $0,3,6$, and 9 .

Sampling and Analysis of Feed and Milk. Samples of TMR and feed ingredients were taken once on each of wk 0,2, 4, 6, and 8. Orts from each animal were sampled once on each of wk 0,4 , and 8. Samples of TMR, ingredients, and orts were analyzed as described for Experiment 1.

Milk was sampled as described for Experiment 1 from each cow at a.m. and p.m. milking on the last day of wk 0, 2, 4, and 8. As with Experiment 1, a portion of milk from each cow was preserved with potassium dichromate and analyzed for protein, fat, lactose, and 
SCC using near infrared spectroscopy at the Alberta Agriculture, Food and Rural Development Central Milk Testing Laboratory. The rest of the milk was stored at $-20^{\circ} \mathrm{C}$ for later analysis.

Lipids for FA analysis were extracted from the milk as described for Experiment 1. The FA were then methylated as per Experiment 1 with minor modifications. Two milliliters of hexane was added to the $20-\mathrm{mL}$ glass scintillation vial to resolubilize the fat. The hexane containing the fat was then transferred into a $14-\mathrm{mL}$ screwtop tube. Forty microliters of methyl acetate was added. Following vortexing, $80 \mu \mathrm{L}$ of methylating agent $(0.5$ $M$ sodium methoxide) was added. The mixture was vortexed and incubated for $15 \mathrm{~min}$ in a $50^{\circ} \mathrm{C}$ water bath. The reaction was stopped by adding $60 \mu \mathrm{L}$ of termination reagent $(1 \mathrm{~g}$ of oxalic acid in $30 \mathrm{~mL}$ of diethyl ether). Two milliliters of water was added to remove any nonlipid material. The sample was vortexed and centrifuged at $2,400 \times g$ for $5 \mathrm{~min}$, leaving a clear layer of hexane from which an aliquot was taken for gas chromatography analysis.

The FAME were analyzed on a Varian 3600 gas chromatograph with a temperature-programmable injector and flame-ionization detector. Separation of the FAME was performed using an SP2560 fused silica capillary column $[100 \mathrm{~m} \times 0.25 \mathrm{~mm}$ (i.d.) with $0.25-\mu \mathrm{m}$ film thickness] (Supelco). Purified helium (Praxair) was used as the carrier gas with a head pressure of $25 \mathrm{psi}$ and a flow rate of $1 \mathrm{~mL} / \mathrm{min}$. The initial column temperature was set at $40^{\circ} \mathrm{C}$ and held for $4 \mathrm{~min}$, increased to $175^{\circ} \mathrm{C}$ at $13^{\circ} \mathrm{C} / \mathrm{min}$ and held for $25 \mathrm{~min}$, further increased to $215^{\circ} \mathrm{C}$ at $4^{\circ} \mathrm{C} / \mathrm{min}$ and held for $23 \mathrm{~min}$, and finally increased to $230^{\circ} \mathrm{C}$ at $5^{\circ} \mathrm{C} / \mathrm{min}$ and held for $17.5 \mathrm{~min}$. The initial injector temperature was $60^{\circ} \mathrm{C}$, held for 0.2 $\mathrm{min}$, then increased at $150^{\circ} \mathrm{C} / \mathrm{min}$ to $250^{\circ} \mathrm{C}$ and held for $88 \mathrm{~min}$. The detector temperature was set at $250^{\circ} \mathrm{C}$. Peak area was measured using the Shimadzu ClassVP chromatography data system. Peaks were identified using Nu-Chek Prep standards \#85 and \#411. Conjugated linoleic acids isomers were identified using standards from Matreya. Trans-11, cis-15 18:2 was identified by cross-referencing with previously published isomeric profiles reported for milk fat produced under similar analytical conditions (Ulberth and Henninger, 1994; Precht and Molkentin, 1997) using cis-9, cis-12 18:2 as a landmark isomer. Detector response for individual FA was verified using $\mathrm{Nu}$-Chek Prep standard \#60. Each FA was reported as a percentage of FAME.

Separation of the octadecenoic acids was carried out on milk samples collected during wk $0,2,4$, and 8 using a gas chromatograph (5890; Hewlett-Packard, Wilmington, DE) equipped with a flame-ionization detector, automatic injector, split injection port, and a 100$\mathrm{m}$ fused silica capillary column (i.d. $=0.25 \mathrm{~mm}$ ) coated with $0.2-\mu \mathrm{m}$ film of cyanopropyl polysiloxane (CP-SIL 88, Chrompack). Helium was used as the carrier gas. Injector and detector temperatures were maintained at 240 and $260^{\circ} \mathrm{C}$, respectively, and the sample $(1 \mu \mathrm{L})$ was injected using split ratio of 1:50. The FAME profile of octadecenoic acids was determined using the following temperature program. Column temperature was maintained at $70^{\circ} \mathrm{C}$ for $1 \mathrm{~min}$, increased to $170^{\circ} \mathrm{C}$ at a rate of $30^{\circ} \mathrm{C} / \mathrm{min}$, and held at this temperature for $54 \mathrm{~min}$. As a final step, column temperature was increased to $220^{\circ} \mathrm{C}$ at a rate of $30^{\circ} \mathrm{C} / \mathrm{min}$ and held at this temperature for $15 \mathrm{~min}$. Separation of trans and cis octadecenoic acids was incomplete, but the chromatography allowed the major isomers of interest to be resolved. Trans-6, trans-7 and trans-8 18:1 isomers, as well as trans-13 and trans-14 18:1 isomers remained unresolved as single peaks. Individual trans isomers were identified by cross-referencing with previously published isomeric profiles reported for milk fat produced under similar analytical conditions (Precht and Molkentin, 1997; Griinari et al., 1998; Precht et al., 2001) using trans-11 18:1 as a landmark isomer.

Milk for vitamin analysis was stored in opaque containers at $-20^{\circ} \mathrm{C}$, and vitamin extraction and preparation were performed away from direct sunlight. Vitamin E was extracted from milk using a method adapted from the procedure of Brubacher et al. (1985). Milk was thawed at $27^{\circ} \mathrm{C}$. A 5 -mL sample of the thawed milk was placed in a $50-\mathrm{mL}$ tube. Twenty-five milliliters of methanol (containing $1.25 \mathrm{~g}$ of ascorbic acid and $5 \mathrm{mg}$ of butylated hydroxytoluene) was added. After the addition of $5 \mathrm{~mL}$ of potassium hydroxide $(50 \%$, wt/vol in water), the tube was flushed with nitrogen and capped. The tube was inverted to mix contents, placed in an $80^{\circ} \mathrm{C}$ water bath for $20 \mathrm{~min}$ with periodic agitation, and then cooled to $30^{\circ} \mathrm{C}$. The vitamin $\mathrm{E}$ was then extracted using heptane (Hidiroglou, 1989; Jensen and Nielsen, 1996). Five milliliters of heptane was added to the tube followed by vortexing for 1 to $2 \mathrm{~min}$. The phases were then separated by centifugation at 1,500 $\times g$ for $5 \mathrm{~min}$. The heptane layer was transferred to a $20-\mathrm{mL}$ scintillation vial and evaporated under nitrogen at $40^{\circ} \mathrm{C}$. The extraction procedure was repeated with another $5 \mathrm{~mL}$ of heptane, which was transferred to the same scintillation vial for evaporation. After evaporation, the residue was dissolved in $500 \mu \mathrm{L}$ of acetone:chloroform (3:7, vol/ vol) and transferred to an HPLC vial for immediate analysis.

Vitamin E was analyzed using a Waters 2690 HPLC system (Waters Associates Inc, Milford, MA) fitted with a Supelcosil RP LC-18 column $(15 \mathrm{~cm} \times 4.6 \mathrm{~mm} \times 3$ $\mu \mathrm{m}$; Supelco Canada Ltd., Oakville, ON, Canada). The mobile phase was acetonitrile:methanol $(75: 25$, vol/vol) with a flow rate of $1 \mathrm{~mL} / \mathrm{min}$ at a run time of $22 \mathrm{~min}$. 
BELL ET AL.

Table 3. Dry matter intake, milk yield, and milk composition during the 15-d treatment period (Experiment 1)

\begin{tabular}{lccccc}
\hline & \multicolumn{3}{c}{ Diet $^{1}$} & \\
\cline { 2 - 5 } & CTL & MON & SAFF & SAFF/M & SEM \\
\hline DMI, kg/d & 20.45 & 20.25 & 18.39 & 19.52 & 0.74 \\
Milk yield, ${ }^{2} \mathrm{~kg} / \mathrm{d}$ & 26.87 & 27.58 & 26.78 & 27.83 & 1.48 \\
Fat, ${ }^{\text {\% }}$ & $4.02^{\mathrm{a}}$ & $3.57^{\mathrm{a}}$ & $2.83^{\mathrm{b}}$ & $2.95^{\mathrm{b}}$ & 0.16 \\
Fat yield, kg/d & $1.05^{\mathrm{a}}$ & $0.97^{\mathrm{a}}$ & $0.74^{\mathrm{b}}$ & $0.81^{\mathrm{b}}$ & 0.05 \\
Protein, \% & 3.32 & 3.38 & 3.11 & 3.23 & 0.10 \\
Protein yield, kg/d & 0.87 & 0.92 & 0.82 & 0.88 & 0.05 \\
Lactose, \% & 4.30 & 4.54 & 4.26 & 4.50 & 0.09 \\
Lactose yield, kg/d & 1.13 & 1.24 & 1.14 & 1.24 & 0.08 \\
\hline
\end{tabular}

${ }^{\mathrm{a}, \mathrm{b}}$ Within a row, values with different superscripts are significantly different $(P<0.05)$.

${ }^{1}$ Diets were control (CTL) and control supplemented with monensin (MON), safflower oil (SAFF), and safflower oil plus monensin (SAFF/M).

${ }^{2}$ Average milk yield over the last $8 \mathrm{~d}$ of the treatment period.

${ }^{3}$ Values for fat, protein, and lactose represent average values for milk taken from the last $2 \mathrm{~d}$ of the treatment period.

Vitamin E was determined using a Shimadzu RF-535 Fluorescence monitor (Shimadzu Scientific Instruments Inc.) with wavelength settings of 295 and 330 $\mathrm{nm}$ for excitation and emission, respectively. Peak area was measured using the Shimadzu Class-VP chromatography data system. Vitamin E was quantified by comparison of peak areas to a standard curve of $\alpha$ tocopherol (Sigma-Aldrich, Inc., Mississauga, ON, Canada).

\section{Statistical Analyses}

Data from both experiments were analyzed statistically as a randomized block design with a repeated measures treatment structure using the MIXED procedure of SAS version 8.3 (SAS Inst., Inc., Cary, NC). Cow within treatment was the experimental unit, and week of sampling was the repeated measure. Treatment, week, block, and treatment by week interaction were fixed effects; cow was the random effect. The Kenward-Roger option was used to estimate denominator degrees of freedom. The variance-covariance matrix structure was chosen for each statistical model in a process wherein the best fit was chosen based on the Schwarz's Bayesian criterion. Least squares means were estimated and separated using the pdiff option when fixed effects were significant $(P<0.05)$.

\section{RESULTS AND DISCUSSION}

\section{Experiment 1}

DMI, Milk Yield, and Milk Composition. The effect of diet on DMI, milk yield, and milk composition is presented in Table 3. Dry matter intake and milk yield were not significantly different between treat- ments. Percentage and yield of protein and lactose were also not significantly different between treatments in this study. Both percentage and yield of fat were significantly reduced when diets were supplemented with safflower oil. Addition of monensin to the SAFF diet did not produce a further decrease. Consistent with this, only a slight reduction in milk fat was observed for MON compared with the control $(P<0.06)$. A similar effect of monensin on milk fat has been observed by others (Sauer et al., 1998; Dhiman et al., 1999). However, the effect of safflower oil on milk fat yield $(-30 \%)$ was greater than expected given that a high-forage basal diet was fed in this experiment (Table 1). Previous work indicates that a diet-induced change in rumen environment, such as the change induced by a low level of effective fiber is required to observe a significant reduction in milk fat synthesis when plant oils are fed (Griinari et al., 1998). Kalscheur et al. (1997) also provide an example of minimal effect of plant oil supplementation on milk fat on diets that maintain a normal rumen environment. Dietary supplementation with fish oil represents a deviation from the general rule, as it will induce milk fat depression when high forage diets are fed (Offer et al., 1999; Palmquist and Griinari, 2001). This study used a level of plant oil supplementation (6\% of diet DM) that is higher than any previous study reported in the literature; thus, it cannot be excluded that a high level of safflower oil addition has a unique effect on rumen biohydrogenation similar to fish oil fed at a lower level $(<2 \%$ of diet DM). The other possible explanation for the safflower effect on milk fat is that the basal diet altered rumen environment sufficiently for SAFF to express a milk fat-depressing effect. Chemical composition of the diet (Table 1), however, does not reveal anything that might be contribut- 
Table 4. Milk fatty acid (FA) composition during the 15-d treatment period (Experiment 1)

\begin{tabular}{|c|c|c|c|c|c|}
\hline \multirow[b]{2}{*}{$\mathrm{FA}^{2}$} & \multicolumn{4}{|c|}{$\operatorname{Diet}^{1}$} & \multirow[b]{2}{*}{ SEM } \\
\hline & CTL & MON & SAFF & SAFF/M & \\
\hline $4: 0$ & $5.17^{\mathrm{a}}$ & $4.82^{\mathrm{a}}$ & $5.08^{\mathrm{a}}$ & $4.06^{\mathrm{b}}$ & 0.20 \\
\hline $6: 0$ & $3.38^{\mathrm{a}}$ & $3.20^{\mathrm{a}}$ & $2.48^{\mathrm{b}}$ & $2.14^{\mathrm{b}}$ & 0.12 \\
\hline $8: 0$ & $1.98^{\mathrm{a}}$ & $1.87^{\mathrm{a}}$ & $1.24^{\mathrm{b}}$ & $1.13^{\mathrm{b}}$ & 0.06 \\
\hline $10: 0$ & $4.23^{\mathrm{a}}$ & $4.20^{\mathrm{a}}$ & $2.18^{\mathrm{b}}$ & $2.06^{\mathrm{b}}$ & 0.15 \\
\hline 11:0 & $0.65^{\mathrm{a}}$ & $0.61^{\mathrm{a}}$ & $0.26^{\mathrm{b}}$ & $0.23^{\mathrm{b}}$ & 0.03 \\
\hline $12: 0$ & $4.80^{\mathrm{a}}$ & $4.79^{\mathrm{a}}$ & $2.44^{\mathrm{b}}$ & $2.40^{\mathrm{b}}$ & 0.13 \\
\hline $13: 0$ & $0.25^{\mathrm{b}}$ & $0.31^{\mathrm{a}}$ & $0.14^{\mathrm{c}}$ & $0.15^{\mathrm{c}}$ & 0.02 \\
\hline $14: 0$ & $13.78^{\mathrm{a}}$ & $14.17^{\mathrm{a}}$ & $9.09^{\mathrm{b}}$ & $9.16^{\mathrm{b}}$ & 0.23 \\
\hline $14: 1$ & $1.36^{\mathrm{ab}}$ & $1.44^{\mathrm{a}}$ & $0.84^{\mathrm{c}}$ & $1.01^{\mathrm{bc}}$ & 0.12 \\
\hline $15: 0$ & $1.68^{\mathrm{b}}$ & $1.92^{\mathrm{a}}$ & $0.97^{\mathrm{c}}$ & $0.98^{\mathrm{c}}$ & 0.06 \\
\hline $16: 0$ & $33.36^{\mathrm{a}}$ & $32.25^{\mathrm{a}}$ & $18.90^{\mathrm{b}}$ & $18.66^{\mathrm{b}}$ & 0.90 \\
\hline $16: 1 \mathrm{n}-7$ & $1.87^{\mathrm{a}}$ & $1.96^{\mathrm{a}}$ & $1.11^{\mathrm{b}}$ & $1.20^{\mathrm{b}}$ & 0.17 \\
\hline $18: 0$ & $5.73^{\mathrm{b}}$ & $5.21^{\mathrm{b}}$ & $8.98^{\mathrm{a}}$ & $8.02^{\mathrm{a}}$ & 0.36 \\
\hline trans $-18: 1^{3}$ & $1.40^{\mathrm{c}}$ & $1.54^{\mathrm{c}}$ & $9.56^{\mathrm{b}}$ & $13.53^{\mathrm{a}}$ & 0.76 \\
\hline cis-18:1 n-9 $9^{4}$ & $11.59^{\mathrm{c}}$ & $12.05^{\mathrm{c}}$ & $18.47^{\mathrm{a}}$ & $16.72^{\mathrm{b}}$ & 0.47 \\
\hline $18: 1 \mathrm{n}-7$ & $0.61^{\mathrm{b}}$ & $0.63^{\mathrm{b}}$ & $0.86^{\mathrm{a}}$ & $0.83^{\mathrm{a}}$ & 0.02 \\
\hline trans- 11, cis-15 18:2 & $0.16^{\mathrm{b}}$ & $0.18^{\mathrm{b}}$ & $0.42^{\mathrm{a}}$ & $0.40^{\mathrm{a}}$ & 0.01 \\
\hline $18: 2 \mathrm{n}-6$ & $1.38^{\mathrm{b}}$ & $1.49^{\mathrm{b}}$ & $2.69^{\mathrm{a}}$ & $2.58^{\mathrm{a}}$ & 0.08 \\
\hline $18: 3 n-3$ & $0.39^{\mathrm{ab}}$ & $0.41^{\mathrm{a}}$ & $0.35^{b c}$ & $0.34^{\mathrm{c}}$ & 0.02 \\
\hline $20: 0$ & $0.12^{\mathrm{b}}$ & $0.11^{b}$ & $0.15^{\mathrm{a}}$ & $0.14^{\mathrm{ab}}$ & 0.01 \\
\hline $20: 1 \mathrm{n}-11$ & 0.10 & 0.11 & 0.12 & 0.11 & 0.01 \\
\hline $20: 1 \mathrm{n}-9$ & $0.03^{\mathrm{c}}$ & $0.03^{\mathrm{c}}$ & $0.06^{\mathrm{b}}$ & $0.07^{\mathrm{a}}$ & 0.003 \\
\hline cis -9, trans-11CLA ${ }^{5}$ & $0.45^{\mathrm{c}}$ & $0.52^{\mathrm{c}}$ & $3.36^{\mathrm{b}}$ & $5.15^{\mathrm{a}}$ & 0.23 \\
\hline trans-10, cis-12 CLA & $\mathrm{ND}^{6}$ & $\mathrm{ND}$ & $0.05^{b}$ & $0.08^{a}$ & 0.01 \\
\hline CLA trans/trans & $0.03^{\mathrm{b}}$ & $0.04^{\mathrm{b}}$ & $0.13^{\mathrm{a}}$ & $0.15^{\mathrm{a}}$ & 0.01 \\
\hline Other FA & $4.78^{\mathrm{c}}$ & $5.18^{c}$ & $8.18^{\mathrm{a}}$ & $7.17^{\mathrm{b}}$ & 0.16 \\
\hline
\end{tabular}

\footnotetext{
${ }^{\mathrm{a}-\mathrm{d} W i t h i n}$ a row, values with different superscripts are significantly different $(P<0.05)$.

${ }^{1}$ Diets were control (CTL) and control supplemented with monensin (MON), safflower oil (SAFF), and safflower oil plus monensin (SAFF/M).

${ }^{2}$ All values are presented as a percentage of FA methyl esters.

${ }^{3}$ The major trans-18:1 peak consists of trans-6 to trans-11 18:1.

${ }^{4}$ The major cis-18:1 peak consists of cis-9, trans-13/14 and trans-15 isomers of 18:1

${ }^{5}$ The chromatography methods used were unable to separate the minor quantities of 7/9 and 8/10 CLA isomers from the main cis-9, trans-11 isomer.

${ }^{6} \mathrm{ND}=$ Not detected.
}

ing to the effect on rumen environment. Changes in milk FA composition, discussed in the following section, suggest that SAFF produced changes in biohydrogenation that are associated with the reduction in milk fat synthesis.

Milk FA Composition. The control diet, representative of diets fed in western Canada, resulted in milk fat with a cis-9, trans-11 CLA concentration of $0.45 \%$ (Table 4), similar to that reported for various dairy products (Chin et al., 1992). Cows fed the SAFF diet produced milk fat with $3.36 \%$ cis-9, trans-11 CLA, significantly greater than the control diet. Although monensin alone had no significant effect on milk cis-9, trans-11 CLA, monensin in combination with safflower oil increased milk fat CLA more than safflower oil alone. The concentration of $c i s-9$, trans-11 CLA with SAFF/M was $5.15 \%,>10$ times the level in control milk. The yield (g/d) of cis-9, trans-11 CLA was 4.70, 4.95, 25.79, and 41.97 for the control, MON, SAFF, and SAFF/M, respectively. Hence, although the yield of fat was lower in the SAFF/M treatment, the yield of CLA was still approximately 9 times greater than the yield of CLA with the control.

Milk fat CLA response to the SAFF diet in this study is similar to responses found in studies where oils high in cis-9, cis-12 18:2 were fed along with a basal diet containing corn silage plus high-moisture corn (Kelly et al., 1998; Dhiman et al., 2000; Bauman et al., 2000). The effect of basal diet on milk fat CLA responses when plant oils are fed is also suggested by the study of Chouinard et al. (2001), where the effect of dietary supplementation with extruded full-fat soybeans was examined in 2 experiments. One experiment used a basal diet consisting of alfalfa and grass silage as forage, and the other used corn silage plus grass silage. Milk fat CLA content was $2 \%$ with the diet including corn silage compared with $<1 \%$ with the diet based on hay crop silages. Furthermore, when cis-9, cis-12 18:2-rich oils have been administered to cows fed pasture, milk fat CLA responses have been minimal (Kay et al., 2004). 
Thus, it appears that the milk fat CLA responses in this study are more comparable with responses observed in studies where low forage-/corn silage-based diets are fed than to responses observed when high forage-/hay crop silage-based diets are fed.

The present study used monensin and observed an apparent synergistic effect with safflower oil in increasing the concentration of CLA in milk fat. Sauer et al. (1998) observed an effect of monensin on milk fat CLA that was similar to the effect of the MON diet in this study. However, other studies have found minimal effects (Chouinard et al., 1998; Dhiman et al., 1999). In the current study, SAFF/M diet resulted in increased levels of trans 18:1 and tended to decrease levels of 18:0 $(P<0.07)$ in milk fat, suggesting that the synergistic effect of SAFF and MON also involved inhibition of trans 18:1 reduction in the rumen. In the study by Sauer et al. (1998) trans 18:1 concentration in milk fat increased 3-fold when $24 \mathrm{ppm}$ of monensin was added to the diet. Consistent with the importance of the endogenous synthesis of CLA from trans-11 18:1 (Griinari et al., 2000), concentration of CLA in milk fat also increased from 0.8 to $1.3 \%$ of total FA. Recently, Jenkins et al. (2003) demonstrated that addition of $25 \mathrm{ppm}$ of monensin in a culture of mixed rumen bacteria resulted in inhibition of trans 18:1 reduction and minimal effect on accumulation of CLA. Thus, we conclude that, in the current study, the combination of safflower oil and monensin demonstrates a synergistic effect in inhibiting trans-18:1 reduction in the rumen and subsequent increase in the enhancement of CLA levels in milk fat.

Diet-induced changes in rumen biohydrogenation, resulting in enhanced levels of CLA in milk fat, as discussed previously, are also associated with the decrease in milk fat percentage. The biohydrogenation theory of milk fat depression as proposed by Bauman and Griinari (2001) is based on a concept that, under certain dietary conditions, the pathways of rumen biohydrogenation are altered to produce unique FA intermediates, some of which are potent inhibitors of milk fat synthesis. The only confirmed inhibitor of milk fat synthesis, established by postruminal infusion studies, is the trans-10, cis-12 CLA (Baumgard et al., 2000). The current study finds increased levels of trans-10, cis-12 CLA in milk fat with SAFF and SAFF/M diets, similar to studies involving diet-induced milk fat depression (Piperova et al., 2000; Peterson et al., 2003). Levels of milk trans-10, cis-12 CLA are considerably lower in studies involving diet-induced milk fat depression compared with studies involving postruminal infusions of trans-10, cis-12 CLA at comparable levels of milk fat reduction, suggesting that, in addition to trans-10, cis12 CLA, other inhibitors of milk fat synthesis may be formed in the rumen when milk fat depression is in- duced by the diet (Piperova et al., 2000; Peterson et al., 2003). The interaction between SAFF and MON diets observed relative to concentration of CLA is apparent with regard to the trans-10, cis-12 CLA content in milk fat, but not in terms of fat percentage change. The reason for this discrepant result cannot be explained based on available data.

Even though dairy products contribute only about 15 to $25 \%$ of the total fat in the Western diet, they provide 25 to $35 \%$ of the total saturated fat (Chilliard et al., 2000). Ruminant fat has been associated with an elevation in blood total cholesterol because of its high content of saturated FA and particularly because of its high content of 14:0 and 16:0, which are generally considered hyper-cholesterolemic (Berner, 1993). In this study, we found that diets that increased CLA also resulted in a decrease in the proportion of 14:0 and 16:0 in milk fat. The SAFF and SAFF/M milk compared with control or MON had 33 to $35 \%$ lower 14:0 and 41 to $44 \%$ lower 16:0. The level of cis-9, cis-12 18:2 was also significantly increased with SAFF and SAFF/M, although the level of this FA was still relatively low in the milk fat. This is undoubtedly because of the extensive biohydrogenation that occurs in the rumen (Doreau and Ferlay, 1994). There was no additional increase of cis-9, cis-12 18:2 in milk fat when monensin was added to the diet.

Increase in milk fat CLA content is associated with an increase in total trans FA in milk fat. Dietary trans FA increase low-density lipoprotein cholesterol and decrease high-density lipoprotein cholesterol, thus causing an unfavorable low-density:high-density lipoprotein change (Mensink and Katan, 1990). Unfortunately, there are no controlled dietary studies that compared the effect of trans FA from different sources, i.e., chemical hydrogenation or biohydrogenation. Therefore, an increase in milk fat trans FA content may have a negative impact on perceived nutritional quality of CLAenriched milk fat. It is important to characterize the diet-induced changes in trans FA isomer profiles in more detail, and this was done in Experiment 2.

\section{Experiment 2}

Experiment 1 involved feeding the cows over a 2 -wk period. However, it was not certain whether the effects of the supplemental ingredients on milk CLA would be sustained over a longer period. In particular, questions surrounded the long-term effectiveness of monensin caused by the adaptation of rumen microbes to monensin (Griinari and Bauman, 1999; Chilliard et al., 2000). Experiment 2 also considered the effectiveness of flaxseed oil to increase milk CLA compared with safflower oil and the effect of supplemental vitamin $\mathrm{E}$ on milk CLA concentrations. 
Table 5. Dry matter intake, BW, BCS, milk yield and milk composition during the 8-wk treatment period, independent of week (experiment 2)

\begin{tabular}{lcccccrr}
\hline & \multicolumn{7}{c}{ Diet $^{1}$} \\
\cline { 2 - 6 } & CTL & SAFF & SAFF/E & SAFF/M & SAFF/ME & FLAX/E & SEM \\
\hline DMI, kg/d & $19.06^{\mathrm{a}}$ & $18.75^{\mathrm{ab}}$ & $18.81^{\mathrm{ab}}$ & $17.01^{\mathrm{b}}$ & $17.72^{\mathrm{ab}}$ & $17.76^{\mathrm{ab}}$ & 0.68 \\
BW, kg & 605.4 & 623.8 & 611.3 & 633.2 & 632.58 & 647.3 & 14.55 \\
BCS (1- to 5-point scale) & 2.92 & 3.00 & 2.94 & 2.93 & 3.06 & 3.07 & 0.09 \\
Milk yield, kg/d & 32.02 & 29.81 & 31.01 & 29.89 & 28.52 & 29.36 & 1.44 \\
Lactose, \% & 4.60 & 4.60 & 4.63 & 4.56 & 4.53 & 4.62 & 0.05 \\
Lactose yield, kg/d & 1.45 & 1.33 & 1.43 & 1.36 & 1.26 & 1.33 & 0.07 \\
Protein, \% & 3.04 & 3.06 & 3.13 & 2.98 & 3.18 & 3.12 & 0.08 \\
Protein yield, kg/d & 0.95 & 0.87 & 0.96 & 0.88 & 0.85 & 0.89 & 0.04 \\
Fat, \% & $3.66^{\mathrm{a}}$ & $2.97^{\mathrm{bc}}$ & $3.26^{\mathrm{ac}}$ & $2.85^{\mathrm{c}}$ & $3.28^{\mathrm{ac}}$ & $3.30^{\mathrm{ab}}$ & 0.16 \\
Fat yield, kg/d & $1.15^{\mathrm{a}}$ & $0.85^{\mathrm{b}}$ & $1.02^{\mathrm{ab}}$ & $0.86^{\mathrm{b}}$ & $0.92^{\mathrm{b}}$ & $0.96^{\mathrm{b}}$ & 0.06 \\
Vitamin E, $\mu \mathrm{g} / \mathrm{g}$ of milk & $0.72^{\mathrm{b}}$ & $0.81^{\mathrm{b}}$ & $1.28^{\mathrm{a}}$ & $0.83^{\mathrm{b}}$ & $1.31^{\mathrm{a}}$ & $0.87^{\mathrm{b}}$ & 0.06 \\
\hline
\end{tabular}

${ }^{\mathrm{a}, \mathrm{b}, \mathrm{c}}$ Values within a row with different letters are significantly different $(P<0.05)$.

${ }^{1}$ Diets were control (CTL) and control supplemented with safflower oil (SAFF), safflower oil plus vitamin $\mathrm{E}(\mathrm{SAFF} / \mathrm{E})$, safflower oil plus monensin (SAFF/M), safflower oil plus monensin plus vitamin E (SAFF/ME), and flaxseed plus vitamin E (FLAX/E).

DMI, Milk Yield and Milk Composition. The effects of dietary treatment on DMI, milk yield, and milk composition are presented in Table 5. All groups decreased DMI over the treatment period (week effect, $P<0.0001$ ). The drop in DMI appeared to be more pronounced for the diets containing monensin than for the control diet, and this reached significance for SAFF/M compared with the control. This effect of monensin on DMI has been demonstrated before (Ramanzin et al., 1997; Sauer et al., 1998) and is part of the reason for improved feed efficiency observed with monensin feeding in cattle.

Milk yield was not significantly different between treatments, although the effect of week was significant as yield declined for all groups during the treatment period. Percentage and yield of protein and lactose were not significantly different among treatments. All treatments except the control showed a significant drop in milk fat percentage between wk 0 and 2 (Figure 1). Cows in the FLAX/E group, bounced back by wk 4 and stayed at that level for the remaining 4 wk of the study, resulting in a nonsignificant decrease in average fat percentage compared with the control (Table 5). For the other diets, decrease in fat percentage continued, and it was most pronounced for the SAFF/M diet. Again, the decrease in milk fat with dietary supplementation of plant oils high in polyunsaturated FA was greater than expected given the high proportion of forage in the diet. Although previous work has emphasized the importance of the low forage fiber level and the presence of unsaturated fat as dietary prerequisites for milk fat depression to occur (Bauman and Griinari, 2001), current data suggest that the role of a high level of oil supplementation alone needs to be considered. As discussed earlier, high levels of plant oil (6\% of diet DM) may induce changes in the rumen biohydrogenation that are comparable with the effect of fish oil added at a much lower level $(<2 \%$ of diet DM). Dietary supplementation with monensin did not appear to have any independent effect on milk fat percentage. The addition of vitamin $\mathrm{E}$ appeared to partially protect against this depression in milk fat (Figure 1). In fact, oilseed treatments that contained supplementary vitamin $\mathrm{E}$ (SAFF/

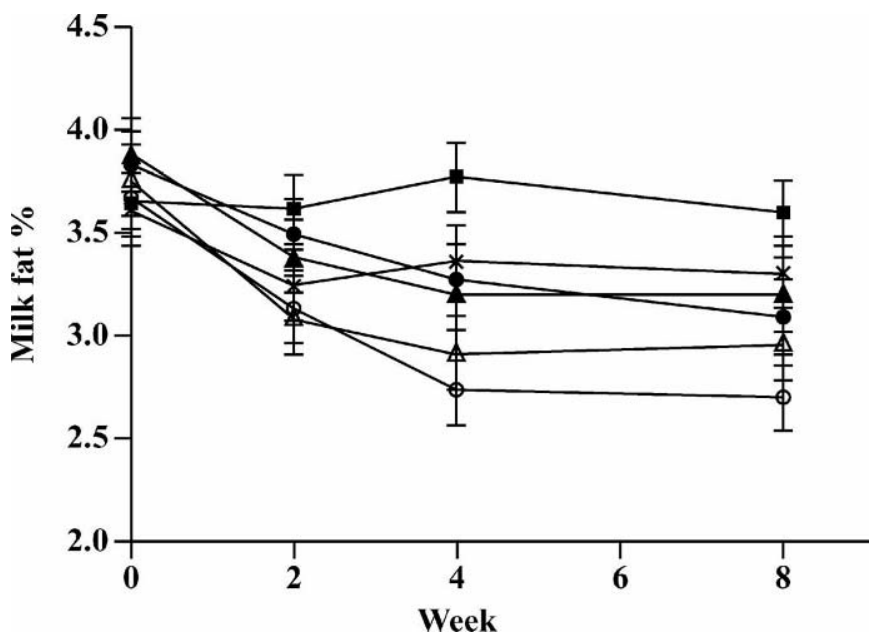

Figure 1. Average milk fat percentage of treatment groups at wk $0,2,4$, and 8 (Experiment 2). Control diet ( $\mathbf{\square})$; control diet including safflower oil at $6 \%$ of DM, $\operatorname{SAFF}(\triangle)$; control diet including safflower oil at $6 \%$ of DM plus vitamin $\mathrm{E}$ at $150 \mathrm{IU}$ of $\mathrm{DM} / \mathrm{kg}$ of DM, SAFF/E (A); control diet including safflower oil at $6 \%$ of DM plus monensin at $24 \mathrm{ppm}$ of DM, SAFF/M (O); control diet including safflower oil at $6 \%$ of DM plus monensin at $24 \mathrm{ppm}$ of DM plus vitamin E at 150 IU/kg of DM, SAFF/ME (O); and control diet including flaxseed oil at $6 \%$ of $\mathrm{DM}$ plus vitamin $\mathrm{E}$ at $150 \mathrm{IU} / \mathrm{kg}$ of $\mathrm{DM}, \mathrm{FLAX} / \mathrm{E}(\times)$. Treatment (excluding wk 0 data), week, and treatment $\times$ week interaction were significant $(P<0.008, P<0.0001, P<0.0001$, respectively). 
E, SAFF/ME, FLAX/E) were not significantly different from the control diet in milk fat percentage, whereas oilseed treatments without vitamin E (SAFF and SAFF/ M) had an overall significantly lower milk fat percentage compared with the control diet (Table 5). Other laboratories have observed a similar effect of vitamin E on bovine milk fat (Charmley and Nicholson, 1993; Charmley and Nicholson, 1994; Focant et al., 1998). Milk samples from the study by Focant et al. (1998) were subsequently analyzed for trans FA, and it was observed that dietary supplementation with vitamin $\mathrm{E}$ $(9,600 \mathrm{IU} / \mathrm{d})$ resulted in reduction of trans-10 18:1 in milk fat, suggesting that the effect of vitamin $\mathrm{E}$ on milk fat percentage was mediated by the changes in rumen biohydrogenation (Larondelle et al., 2002). The suggestion of a biohydrogenation shift is also supported by a recent study by Kay et al. (2005), who found that plasma trans-11 18:1 tended to increase and plasma trans-10 18:1 numerically decreased in dairy cows when the TMR was supplemented with 10,000 IU of $\alpha$-tocopherol/ d. In this experiment, the trans-10 18:1 was significantly reduced for SAFF/ME compared with SAFF/M, but was not significantly different between SAFF and SAFF/E (Table 6).

The vitamin $\mathrm{E}$ content of milk was significantly higher for SAFF/E and SAFF/ME compared with all other treatments (Table 5). The supplementation of vitamin $\mathrm{E}$ was expected to increase the level of vitamin $\mathrm{E}$ in the milk even though the transfer efficiency from diet to milk is known to be relatively low in cows (Hidiroglou, 1989; Focant et al., 1998). It is not certain why the addition of vitamin $\mathrm{E}$ to the diet containing flaxseed oil did not increase vitamin $\mathrm{E}$ in milk to a similar extent as $\mathrm{SAFF} / \mathrm{E}$ and $\mathrm{SAFF} / \mathrm{ME}$, even though this diet had levels of vitamin $\mathrm{E}$ similar to $\mathrm{SAFF} / \mathrm{E}$ and $\mathrm{SAFF} / \mathrm{ME}$ (data not shown).

Milk FA Composition. The effect of dietary treatment on milk FA composition is shown in Table 6. The main characteristics of the safflower oil and flaxseed oil were to some extent reflected in the milk FA composition. The addition of safflower or flaxseed oil significantly raised the level of $c i s-9$, cis-12 18:2 in the milk compared with the control, although this was much more pronounced for the safflower diets than for the flaxseed diet. The addition of flaxseed to the diet increased the level of cis-9, cis-12, cis-15 18:3 in milk compared with the control or safflower treatments. Although a significant increase in cis-9, cis-12 18:2 and cis-9, cis-12, cis-15 18:3 was observed in milk, the overall increase in these FA in milk was relatively small, most likely because of extensive biohydrogenation in the rumen, as discussed previously.

The addition of safflower and flaxseed oil reduced the level of $16: 0$ and 14:0 in the milk by, on average, 40.1 and $28.1 \%$, respectively (Table 6). This is similar to what was observed in Experiment 1. Because 16:0 and 14:0 have been implicated as being hypercholesterolemic, the large decrease in their concentration observed in this study is an additional benefit (Noakes et al., 1996). The concentration of the short- to medium-chain FA (4:0 to 15:0) in milk were also reduced as a result of safflower and flaxseed oil feeding as is typically observed when the dairy diet is supplemented with fats and oils (Chilliard et al., 2000).

As discussed earlier, the effect of dietary treatments on milk fat CLA levels are mediated through the effects of the diet on rumen biohydrogenation, and in that respect, the accumulation of trans-11 18:1 in the rumen is the main driver for CLA synthesis in the mammary gland. Again, addition of safflower oil resulted in increases in all milk fat trans 18:1 isomers with the most pronounced increase in trans-11 18:1 (Table 6). The proportion of total trans 18:1 increase attributable to increase in trans-11 18:1 varied between 57 and $75 \%$, being lowest for FLAX/E and highest for SAFF/ME. Subsequent increases in milk fat cis-9, trans-11 CLA levels were similar to the levels observed in the first experiment.

Addition of monensin further increased SAFF-induced trans 18:1 accumulation in the rumen as demonstrated by significant increases in milk fat levels of total trans 18:1 (Table 6). Cis-9, trans-11 CLA levels tended to be higher when SAFF and SAFF/E diets were supplemented with monensin. However, the difference between SAFF and SAFF/M diets did not reach significance. Detailed analysis of trans 18:1 profiles (Table 6) revealed that the increase in total trans 18:1 compared with the control when SAFF/M was fed was attributable to a smaller increase in trans-11 18:1 (66\%) and a greater increase in trans-10 18:1 (21\%) compared with 72 and $7 \%$ proportional increases, respectively, in these isomers when SAFF was fed. In other words, monensin might have shifted biohydrogenation toward the pathway that produces trans-10 18:1 as an intermediate. The effect was not pronounced, and the shift was not observed in all cows, but it explains the lack of significant increase in milk fat CLA caused by monensin in experiment 2 in contrast to Experiment 1.

Proportion of trans-10 18:1 of total trans 18:1 in milk fat can be used as an indicator of the trans-10 biohydrogenation shift. In this experiment, the average proportion of trans-10 18:1 of total trans 18:1 in milk fat was $11 \%$. When a cut-off of $20 \%$ for this ratio was used, incident cases of trans-10 shift were clearly identified. In the FLAX/E group, there were no incidences of trans10 shift ( 0 cases per 30 observations), one case in the $\mathrm{SAFF}$ group, 6 cases in the SAFF/E group, 9 cases in the $\mathrm{SAFF} / \mathrm{M}$ group, and 3 cases in the SAFF/ME group. 
Table 6. Milk fatty acid (FA) composition during the 8-wk treatment period, independent of week (Experiment 2)

\begin{tabular}{|c|c|c|c|c|c|c|c|}
\hline \multirow[b]{2}{*}{$\mathrm{FA}^{2}$} & \multicolumn{6}{|c|}{ Diet $^{1}$} & \multirow[b]{2}{*}{ SEM } \\
\hline & CTL & SAFF & $\mathrm{SAFF} / \mathrm{E}$ & SAFF/M & SAFF/ME & FLAX/E & \\
\hline $4: 0$ & $4.12^{\mathrm{a}}$ & $2.77^{\mathrm{c}}$ & $3.04^{b c}$ & $2.81^{\mathrm{c}}$ & $2.93^{b c}$ & $3.23^{\mathrm{b}}$ & 0.13 \\
\hline $6: 0$ & $2.37^{\mathrm{a}}$ & $1.39^{\mathrm{b}}$ & $1.54^{\mathrm{b}}$ & $1.42^{\mathrm{b}}$ & $1.50^{\mathrm{b}}$ & $1.56^{\mathrm{b}}$ & 0.07 \\
\hline $8: 0$ & $1.19^{\mathrm{a}}$ & $0.63^{b}$ & $0.70^{\mathrm{b}}$ & $0.64^{b}$ & $0.68^{b}$ & $0.70^{\mathrm{b}}$ & 0.04 \\
\hline $10: 0$ & $2.53^{\mathrm{a}}$ & $1.26^{\mathrm{b}}$ & $1.40^{\mathrm{b}}$ & $1.27^{\mathrm{b}}$ & $1.38^{\mathrm{b}}$ & $1.38^{b}$ & 0.08 \\
\hline $11: 0$ & $0.34^{\mathrm{a}}$ & $0.14^{\mathrm{d}}$ & $0.17^{\mathrm{bc}}$ & $0.14^{\mathrm{cd}}$ & $0.16^{\text {bd }}$ & $0.18^{b}$ & 0.01 \\
\hline $12: 0$ & $2.87^{\mathrm{a}}$ & $1.53^{\mathrm{b}}$ & $1.67^{\mathrm{b}}$ & $1.55^{\mathrm{b}}$ & $1.64^{\mathrm{b}}$ & $1.64^{\mathrm{b}}$ & 0.09 \\
\hline $13: 0$ & $0.20^{\mathrm{a}}$ & $0.10^{\mathrm{b}}$ & $0.13^{b}$ & $0.11^{b}$ & $0.12^{\mathrm{b}}$ & $0.12^{\mathrm{b}}$ & 0.01 \\
\hline $14: 0$ & $11.64^{\mathrm{a}}$ & $8.10^{\mathrm{b}}$ & $8.48^{b}$ & $8.32^{b}$ & $8.44^{\mathrm{b}}$ & $8.48^{b}$ & 0.24 \\
\hline $14: 1$ & $0.95^{\mathrm{a}}$ & $0.57^{\mathrm{b}}$ & $0.62^{\mathrm{b}}$ & $0.54^{\mathrm{b}}$ & $0.57^{b}$ & $0.60^{\mathrm{b}}$ & 0.05 \\
\hline $15: 0$ & $1.08^{\mathrm{a}}$ & $0.74^{\mathrm{b}}$ & $0.76^{\mathrm{b}}$ & $0.78^{\mathrm{b}}$ & $0.78^{b}$ & $0.79^{b}$ & 0.02 \\
\hline $16: 0$ & $30.60^{\mathrm{a}}$ & $18.70^{\mathrm{b}}$ & $18.35^{\mathrm{b}}$ & $17.99^{\mathrm{b}}$ & $18.71^{b}$ & $17.87^{\mathrm{b}}$ & 0.54 \\
\hline $16: 1 \mathrm{n}-7$ & $1.53^{\mathrm{a}}$ & $0.96^{\mathrm{b}}$ & $0.95^{\mathrm{b}}$ & $0.90^{\mathrm{b}}$ & $0.96^{\mathrm{b}}$ & $0.91^{\mathrm{b}}$ & 0.05 \\
\hline $18: 0$ & $9.76^{\mathrm{c}}$ & $11.43^{\mathrm{ab}}$ & $11.63^{\mathrm{a}}$ & $10.30^{\mathrm{bc}}$ & $10.51^{\mathrm{abc}}$ & $11.08^{\mathrm{ab}}$ & 0.41 \\
\hline Total trans $18: 1$ & $4.58^{\mathrm{e}}$ & $17.64^{\mathrm{bc}}$ & $16.75^{\mathrm{c}}$ & $21.01^{\mathrm{a}}$ & $18.88^{\mathrm{b}}$ & $14.29^{\mathrm{d}}$ & 0.56 \\
\hline trans-6/8 18:1 & $0.36^{\mathrm{d}}$ & $0.73^{\mathrm{b}}$ & $0.76^{\mathrm{ab}}$ & $0.85^{\mathrm{a}}$ & $0.73^{\mathrm{b}}$ & $0.61^{\mathrm{c}}$ & 0.04 \\
\hline trans-9 18:1 & $0.33^{c}$ & $0.69^{\mathrm{a}}$ & $0.68^{\mathrm{a}}$ & $0.67^{\mathrm{a}}$ & $0.62^{\mathrm{ab}}$ & $0.56^{b}$ & 0.03 \\
\hline trans-10 $18: 1$ & $0.49^{b}$ & $1.40^{\mathrm{b}}$ & $2.08^{b}$ & $3.87^{\mathrm{a}}$ & $2.09^{\mathrm{ab}}$ & $0.63^{b}$ & 0.62 \\
\hline trans-11 18:1 & $1.41^{\mathrm{c}}$ & $10.72^{\mathrm{a}}$ & $8.53^{\mathrm{b}}$ & $12.19^{\mathrm{a}}$ & $12.19^{\mathrm{a}}$ & $6.67^{\mathrm{b}}$ & 0.69 \\
\hline trans-12 18:1 & $0.39^{c}$ & $1.03^{\mathrm{ab}}$ & $1.05^{\mathrm{a}}$ & $0.87^{\mathrm{ab}}$ & $0.84^{\mathrm{b}}$ & $1.04^{\mathrm{ab}}$ & 0.07 \\
\hline trans-13/14 18:1 & $0.77^{\mathrm{e}}$ & $1.56^{\mathrm{bc}}$ & $1.60^{\mathrm{b}}$ & $1.32^{\mathrm{cd}}$ & $1.22^{\mathrm{d}}$ & $2.52^{\mathrm{a}}$ & 0.10 \\
\hline trans-15 18:1 & $0.37^{\mathrm{d}}$ & $0.63^{\mathrm{b}}$ & $0.66^{b}$ & $0.52^{\mathrm{c}}$ & $0.50^{\mathrm{c}}$ & $1.11^{\mathrm{a}}$ & 0.04 \\
\hline trans-16 18:1 & $0.47^{\mathrm{d}}$ & $0.85^{\mathrm{b}}$ & $0.87^{\mathrm{b}}$ & $0.72^{\mathrm{c}}$ & $0.69^{c}$ & $1.14^{\mathrm{a}}$ & 0.03 \\
\hline cis-9 18:1 & $17.69^{\mathrm{ab}}$ & $17.43^{\mathrm{ac}}$ & $17.45^{\mathrm{ac}}$ & $15.78^{\mathrm{c}}$ & $16.54^{\mathrm{bc}}$ & $19.23^{\mathrm{a}}$ & 0.68 \\
\hline cis-11 18:1 & 0.50 & 0.64 & 0.52 & 0.61 & 0.54 & 0.53 & 0.05 \\
\hline cis-12 18:1 & $0.49^{\mathrm{d}}$ & $2.44^{\mathrm{a}}$ & $2.47^{\mathrm{a}}$ & $1.88^{b}$ & $1.78^{\mathrm{b}}$ & $1.47^{\mathrm{c}}$ & 0.10 \\
\hline cis-15 18:1 & $0.23^{\mathrm{c}}$ & $0.31^{b}$ & $0.32^{\mathrm{b}}$ & $0.30^{\mathrm{b}}$ & $0.28^{\mathrm{bc}}$ & $1.06^{\mathrm{a}}$ & 0.02 \\
\hline trans-11, cis-15 18:2 & $0.43^{\mathrm{b}}$ & $0.57^{\mathrm{b}}$ & $0.54^{\mathrm{b}}$ & $0.55^{\mathrm{b}}$ & $0.52^{\mathrm{b}}$ & $2.99^{\mathrm{a}}$ & 0.08 \\
\hline $18: 2 \mathrm{n}-6$ & $1.75^{\mathrm{c}}$ & $2.89^{\mathrm{a}}$ & $2.82^{\mathrm{a}}$ & $2.96^{\mathrm{a}}$ & $2.81^{\mathrm{a}}$ & $2.01^{b}$ & 0.08 \\
\hline $18: 3 n-3$ & $0.41^{b}$ & $0.32^{c}$ & $0.33^{c}$ & $0.32^{\mathrm{c}}$ & $0.32^{\mathrm{c}}$ & $0.73^{\mathrm{a}}$ & 0.01 \\
\hline $20: 0$ & $0.20^{\mathrm{b}}$ & $0.17^{\mathrm{b}}$ & $0.18^{\mathrm{b}}$ & $0.16^{\mathrm{b}}$ & $0.17^{\mathrm{b}}$ & $0.53^{\mathrm{a}}$ & 0.02 \\
\hline $20: 1 \mathrm{n}-11$ & $0.17^{\mathrm{a}}$ & $0.13^{\mathrm{b}}$ & $0.13^{\mathrm{b}}$ & $0.12^{\mathrm{b}}$ & $0.12^{\mathrm{b}}$ & $0.18^{\mathrm{a}}$ & 0.01 \\
\hline $20: 1 \mathrm{n}-9$ & $0.07^{\mathrm{d}}$ & $0.09^{c}$ & $0.08^{\mathrm{cd}}$ & $0.11^{b}$ & $0.10^{\mathrm{bc}}$ & $0.24^{\mathrm{a}}$ & 0.01 \\
\hline cis-9, trans-11 $\mathrm{CLA}^{3}$ & $0.68^{d}$ & $4.12^{\mathrm{ab}}$ & $3.48^{\mathrm{bc}}$ & $4.55^{\mathrm{a}}$ & $4.75^{\mathrm{a}}$ & $2.80^{\mathrm{c}}$ & 0.31 \\
\hline trans -10 , cis -12 CLA & $\mathrm{ND}^{\mathrm{c}}$ & $0.04^{\mathrm{b}}$ & $0.06^{\mathrm{ab}}$ & $0.09^{\mathrm{a}}$ & $0.06^{\mathrm{ab}}$ & $\mathrm{ND}^{\mathrm{c}}$ & 0.01 \\
\hline Saturated $(\mathrm{S})$ & $66.90^{\mathrm{a}}$ & $46.95^{\mathrm{b}}$ & $48.05^{\mathrm{b}}$ & $45.50^{\mathrm{b}}$ & $47.03^{\mathrm{b}}$ & $47.55^{\mathrm{b}}$ & 0.91 \\
\hline Unsaturated (U) & $27.44^{\mathrm{c}}$ & $45.20^{\mathrm{ab}}$ & $43.85^{\mathrm{b}}$ & $47.18^{\mathrm{a}}$ & $45.96^{\mathrm{ab}}$ & $43.33^{b}$ & 0.90 \\
\hline $\mathrm{U}: \mathrm{S}$ & $0.41^{\mathrm{c}}$ & $0.98^{\mathrm{ab}}$ & $0.93^{\mathrm{b}}$ & $1.04^{\mathrm{a}}$ & $0.99^{\mathrm{ab}}$ & $0.92^{\mathrm{b}}$ & 0.03 \\
\hline
\end{tabular}

${ }^{\mathrm{a}-\mathrm{e}}$ Values within a row with different letters are significantly different $(P<0.05)$.

${ }^{1}$ Diets were control (CTL) and control supplemented with safflower oil (SAFF), safflower oil plus vitamin $\mathrm{E}(\mathrm{SAFF} / \mathrm{E})$, safflower oil plus monensin (SAFF/M), safflower oil plus monensin plus vitamin E (SAFF/ME), and flaxseed plus vitamin E (FLAX/E).

${ }^{2}$ Fatty acids are expressed as a percentage of FA methyl esters.

${ }^{3}$ The chromatography methods used were unable to separate the minor quantities of 7/9 and 8/10 CLA isomers from the main cis-9, trans-11 isomer.

Furthermore, most of the cases in the SAFF/E and SAFF/M groups were attributable to only 2 and 3 individual cows, respectively. With a limited number of cows in each treatment group, the effect of individual differences in susceptibility to trans-10 shift cannot be excluded. Gaynor et al. (1995) demonstrated that the cows vary in their susceptibility to change in rumen biohydrogenation in response to dietary treatments. One or more susceptible cows in one treatment group compared with another group may influence the milk CLA response markedly. This may be a consequence of the dietary treatments, but it may also reflect susceptibility of individual cows randomly assigned to each group.
Vitamin E supplementation tended to reduce the levels of total trans 18:1. The reduction reached significance when vitamin $\mathrm{E}$ was added to the diet with monensin (SAFF/M vs. SAFF/ME). Despite the reduction in total trans 18:1 level in milk fat caused by vitamin $\mathrm{E}$ in the monensin diet (SAFF/ME), level of CLA in milk was not reduced, which was consistent with no change in trans-11 18:1 levels.

The effect of flaxseed oil addition (FLAX/E) on accumulation of trans-11 18:1 in the rumen was less pronounced than the effect of safflower oil (SAFF/E). As a consequence, milk fat cis-9, trans-11 CLA levels were slightly lower with FLAX/E compared with the SAFF/ $\mathrm{E}$ diet, although not significantly (Table 6). However, 
the effect of FLAX/E and SAFF/E on total trans 18:1 plus trans-11, cis-15 18:2 in milk fat was essentially the same (17.28 and $17.29 \%$ of total FA, respectively). Thus, it appears that in this experiment, safflower and flaxseed oil resulted in accumulation of similar amounts of biohydrogenation intermediates, but the profile of biohydrogenation intermediates being formed changed. The characteristic biohydrogenation intermediates of cis-9, cis-12, cis-15 18:3, the major isomer in flaxseed oil, included trans-13/14 18:1, trans-15 18:1, and trans11, cis-15 18:2. Trans-11, cis-15 18:2 was increased 5fold when the FLAX/E diet was fed compared with the control; this biohydrogenation intermediate did not increase when SAFF diets were fed.

In this experiment, dietary treatments resulted in milk levels of trans-11 18:1 and cis-9, trans-11 CLA that are among the highest values published so far. Similar levels of milk enrichment have been observed in studies involving dietary supplementation with fish oil (Palmquist and Griinari, 2001) or low forage, e.g., corn silage-based diets (Bauman et al., 2000). Fish oil and corn silage-based diets modify rumen biohydrogenation and produce high levels of intermediates when plant oils are added to the diet (Griinari and Bauman, 1999). Addition of plant oils to pasture diet does not, in general, result in high levels of biohydrogenation intermediates (Kay et al., 2004.). Therefore, it is peculiar that the high-forage basal diet (Table 2) used in this study facilitated such a pronounced effect on milk fat CLA and associated biohydrogenation intermediates. The reason for the favorable influence of the basal diet is unclear but may be due to the special mix of forages and concentrates used in this study (Table 2). Oils and other supplemental ingredients were mixed with the concentrate prior to the addition of the concentrate to the forage portion of the TMR. This places the oils in close association with that part of the TMR with the smallest particle size, possibly minimizing the exposure time in the rumen because of a faster rate of passage. This study also used a high level of oil supplementation $(6 \%$ of $\mathrm{DM})$, and it is possible that very high levels of dietary C18-polyunsaturated FA inhibit trans 18:1 reduction in the rumen similar to lower levels of fish oil $(<2 \%$ of DM). Chilliard et al. (2003) recently summarized studies involving high levels of soybean and linseed oil supplementation (5 to $6 \%$ of diet DM) in goats fed various types of basal forage. Addition of high levels of sunflower or linseed oil to hay or corn silage-based diets increased CLA content in milk fat up to $4 \%$.

Only a few studies have reported effects of diet on bovine milk CLA $>4 \%$ of total FA (Bauman et al., 2000; Palmquist and Griinari, 2001). These high levels of milk CLA have been produced in studies of short duration,

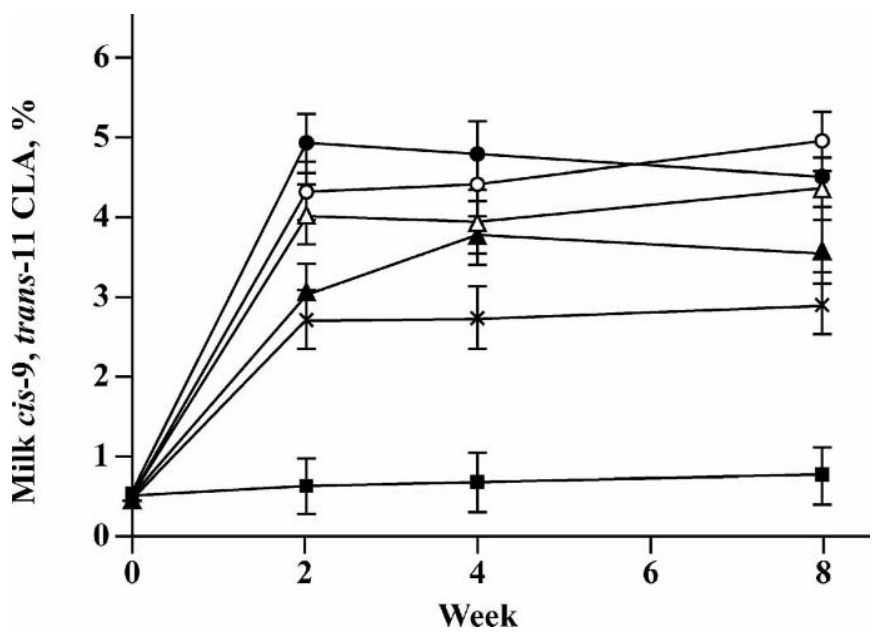

Figure 2. Average percentage of cis-9, trans-11 conjugated linoleic acid (CLA) in milk fat for treatment groups at wk $0,2,4$, and 8 (Experiment 2). Control diet (ם); control diet including safflower oil at $6 \%$ of DM, SAFF $(\triangle)$; control diet including safflower oil at $6 \%$ of $\mathrm{DM}$ plus vitamin $\mathrm{E}$ at $150 \mathrm{IU} / \mathrm{kg}$ of $\mathrm{DM}, \mathrm{SAFF} / \mathrm{E}(\boldsymbol{\Delta})$; control diet including safflower oil at $6 \%$ of DM plus monensin at $24 \mathrm{ppm}$ of DM, $\mathrm{SAFF} / \mathrm{M}(\mathrm{O})$; control diet including safflower oil at $6 \%$ of DM plus monensin at $24 \mathrm{ppm}$ of DM plus vitamin $\mathrm{E}$ at $150 \mathrm{IU} / \mathrm{kg}$ of DM, SAFF/ ME (৩); control diet including flaxseed oil at 6\% of DM plus vitamin $\mathrm{E}$ at $150 \mathrm{IU} / \mathrm{kg}$ of DM, FLAX/E $(\times)$. Treatment (excluding wk 0 data), week, and treatment $\times$ week interaction were significant $(P<0.001$, $P<0.0001, P<0.0001$, respectively).

but the effect has been transitory and typically associated with reduced milk fat percentage (Bauman et al., 2000). In the study by Bauman et al. (2000), the enrichment of milk fat CLA was transient because of biohydrogenation shifting toward trans-10 18:1 as the major intermediate. An associated increase in trans-10, cis12 CLA formation in the rumen resulted in markedly reduced milk fat content (Bauman and Griinari, 2001).

In view of these experiences, the current study examined the effect of the dietary treatments over a period of $8 \mathrm{wk}$. The temporal pattern of milk CLA enrichment as depicted in Figure 2 demonstrates remarkable stability over the whole treatment period. Consistent with the role of trans-11 18:1 as the precursor of milk fat CLA, the levels also demonstrate a sustained increase during the treatment period (Figure 3). Stable levels of cis-9, trans-11 CLA and trans-11 18:1 over time suggest that minimal shifts toward trans-10 18:1 occurred as observed in other studies (Abughazaleh et al., 2004). Thus, these findings are unique, in contrast with the transient changes described in other studies (Bauman et al., 2000; Abughazaleh et al., 2004). An important question regarding monensin was whether it would continue to have an effect beyond 2 wk. As can be seen from Figures 2 and 3, the effect of monensin on cis-9, trans-11 CLA and trans-11 18:1 persisted across the 2mo treatment period. 


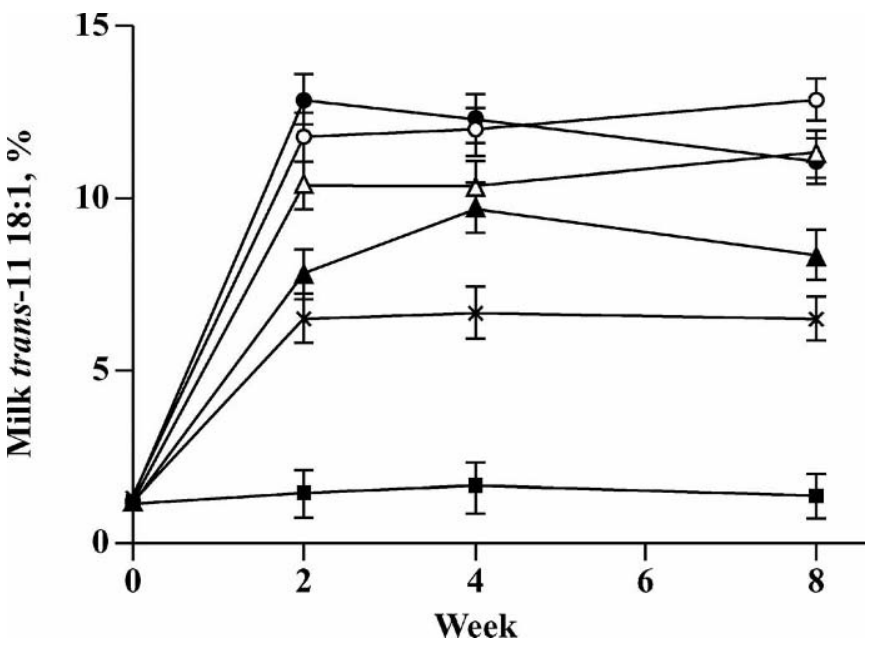

Figure 3. Average percentage of trans-11 18:1 in milk fat for treatment groups at wk 0, 2, 4, and 8 (Experiment 2). Control diet (ם); control diet including safflower oil at $6 \%$ of DM, SAFF $(\triangle)$; control diet including safflower oil at $6 \%$ of DM plus vitamin $\mathrm{E}$ at $150 \mathrm{IU} /$ $\mathrm{kg}$ of DM, SAFF/E ( $\mathbf{\Delta})$; control diet including safflower oil at $6 \%$ of DM plus monensin at $24 \mathrm{ppm}$ of DM, SAFF/M (O); control diet including safflower oil at $6 \%$ of DM plus monensin at $24 \mathrm{ppm}$ of DM plus vitamin $\mathrm{E}$ at $150 \mathrm{IU} / \mathrm{kg}$ of DM, SAFF/ME (-); control diet including flaxseed oil at $6 \%$ of DM plus vitamin $\mathrm{E}$ at $150 \mathrm{IU} / \mathrm{kg}$ of DM, FLAX/E ( $\times$ ). Treatment (excluding wk 0 data), week, and treatment $\times$ week interaction were significant $(P<0.001, P<0.0001, P<0.0001$, respectively).

Variability in milk CLA in response to dietary treatment among individual cows was first described by Kelly et al. (1998) and subsequently observed in many studies. The current study observed a 2 - to 3 -fold variation in milk fat CLA levels among the individual cows. The physiological basis of the variation between individuals has not been established. Solomon et al. (2000) suggested that the variation could be due to differences in rumen biohydrogenation and production of CLA and its precursor, tissue activity of $\Delta^{9}$-desaturase, or a combination of these. Formation of trans-11 18:1 in the rumen is a function of the overall increase in trans 18:1 accumulation in the rumen, as well as the proportion of trans-11 18:1 of total trans 18:1.

As discussed previously, many dietary treatments producing high levels of CLA also induce a shift in the major biohydrogenation pathways characterized by increased accumulation of trans-10 18:1 rather than trans-11 18:1. In this study, all treatments involving safflower oil supplementation had at least one and up to 3 cows per group with consistently low levels of milk fat CLA. In addition, one cow receiving SAFF/ME demonstrated a precipitous drop in milk CLA from 7.81 to $1.65 \%$ of total FA between wk 2 and 8 . Based on detailed analysis of trans 18:1 isomer profiles, it can be concluded that all low-CLA cows, except for one individual, demonstrated an altered trans 18:1 profile with a high

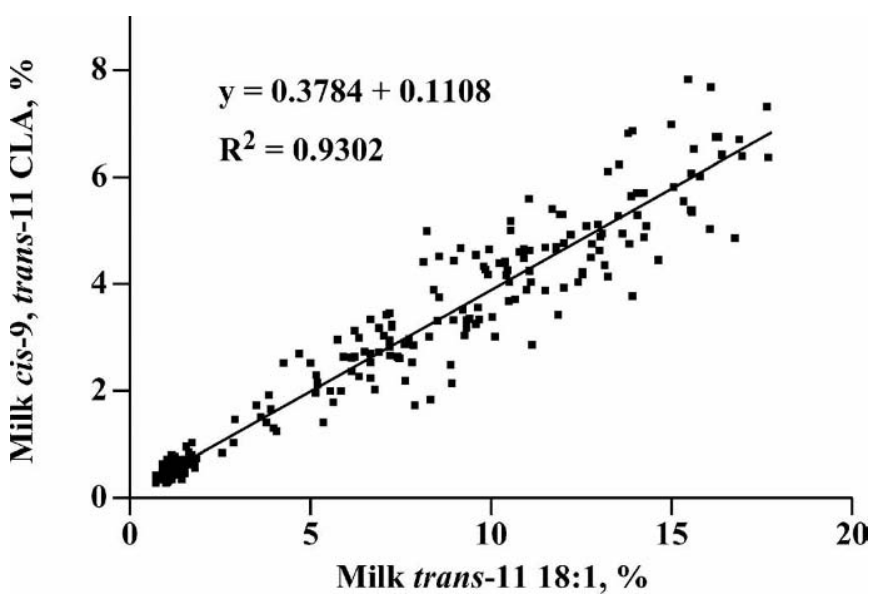

Figure 4. Relationship between cis-9, trans-11 conjugated linoleic acid (CLA) and trans-11 18:1 in milk fat (Experiment 2).

trans-10 18:1 to trans-11 18:1 ratio. The aberrant lowCLA cow was in the SAFF group and demonstrated a low trans-10 18:1 to trans-11 18:1 ratio in milk fat characteristic of high-CLA cows, but had a very low cis9, trans-11 CLA to trans-11 18:1 ratio (0.22), suggesting low $\Delta 9$-desaturase activity.

This study demonstrated a close linear relationship between milk trans-11 18:1 and cis-9, trans-11 CLA contents (Figure 4). Previous studies have reported a similar close relationship for different dietary conditions (Lawless et al., 1998; Griinari and Bauman, 1999). The slope of linear regression varies between data sets, and it is thought to reflect the rate of conversion between trans-11 18:1 and cis-9, trans-11 CLA (i.e., $\Delta^{9}$ desaturase activity in a situation where the supply of preformed cis-9, trans-11 CLA is relatively low; Turpeinen et al., 2002). In the case of a ruminant animal, supply of preformed CLA would mean ruminal supply, and in the case of a monogastric animal, preformed would mean dietary supply. In the current study, the slope of the linear regression (Figure 4) was 0.38. In comparison with this overall value, the low-CLA cow in the SAFF group demonstrates a significantly lower ratio (0.22). Chilliard et al. (2003) found a strong linear correlation between trans-11 18:1 and cis-9, trans-11 CLA across large number of experiments with a slope of 0.40 . They suggest, however, that a very high concentration of trans-11 18:1 induced by diet may exceed the desaturation capacity of the mammary gland within a single study (Chilliard et al., 2003). Linearity of the trans-11 18:1 and cis-9, trans-11 CLA relationship across a wide range of trans-11 18:1 concentrations suggest that the capacity of $\Delta^{9}$-desaturase was not limiting in this experiment, even though the supply of stearic acid and its conversion to oleic acid was not reduced, 


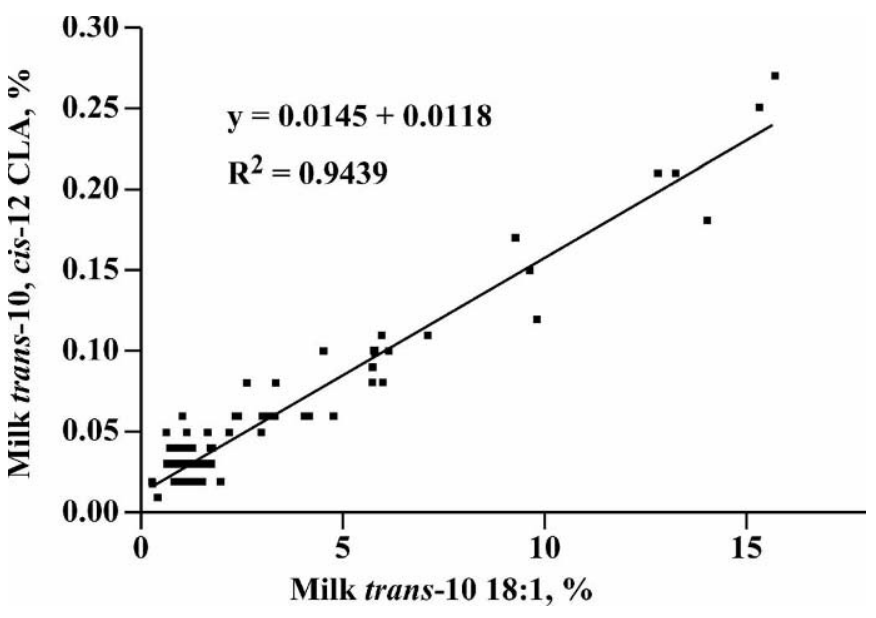

Figure 5. Relationship between trans-10, cis-12 conjugated linoleic acid (CLA) and trans-10 18:1 in milk (Experiment 2).

as indicated by relatively unaltered concentrations of these FA (Table 6.).

Diet-induced decrease in milk fat percentage is generally a consequence of altered rumen biohydrogenation and a shift toward a pathway producing trans-10 18:1 as a major intermediate (Bauman and Griinari, 2001). Studies demonstrating maximal increases in milk CLA have also consistently produced severe decreases in milk fat percentage (Bauman et al., 2000; Palmquist and Griinari, 2001). The current study found that milk fat percentage decreases gradually over a period of 4 wk, after which it levels off. A recently published paper describing the effect of fish meal and extruded soybeans also finds a gradual decrease in milk fat during the first 4 wk of the 10-wk feeding period (Abughazaleh et al., 2004). The effect of known milk fat inhibitors, such as trans-10, cis-12 CLA delivered by abomasal infusion, is very acute, as the inhibitory effect reaches maximum within 4 to $5 \mathrm{~d}$ (Baumgard et al., 2000). The reason for a gradual progression toward reduced milk fat is not obvious. Detailed analysis of trans 18:1 FA in milk fat indicates an increase in prevalence of diet-induced shifts in rumen biohydrogenation, which are likely to be associated with incidence of reduced milk fat. A close linear relationship was observed between milk trans10 18:1 and trans-10, cis-12 CLA (Figure 5). The slope of linear regression (0.015) was relatively similar to the slope value previously observed (0.013) for a group of cows that expressed a transient increase in milk fat CLA (Bauman and Griinari, 2001). Both trans-10 18:1 and trans-10, cis-12 CLA content in milk fat were associated with the degree of milk fat depression (Bauman and Griinari, 2001).

This experiment demonstrates that a feeding strategy allowing for sustained production of highly enriched
CLA milk can be developed. An important question is whether the degree of enrichment achieved is sufficient to provide adequate intake of CLA at realistic levels of dairy consumption. Intake of CLA in North America has been estimated at 52 to $137 \mathrm{mg}$ of CLA/d (Ritzenthaler et al., 2001). Ip et al. (1994) suggested that the level of CLA intake necessary to produce anticarcinogenic effects in humans might be about $3 \mathrm{~g} / \mathrm{d}$ based on direct extrapolation from animal studies. A decade later, this figure of $3 \mathrm{~g}$ is still being reported as the target intake (Campbell et al., 2003), although others have suggested that direct extrapolation may be an overestimation (Ma et al., 2000). Extrapolating on an energy basis rather than a weight basis, Ma et al. (2000) suggested that $600 \mathrm{mg} / \mathrm{d}$ may be a more realistic estimate of a beneficial intake for humans. Using the CLA percentage achieved with the SAFF/M diet (Table 4), one serving of whole milk (420 mg of CLA) and a sandwich with butter (334 mg of CLA) and Cheddar cheese (660 mg of CLA) would provide 1,414 mg of CLA.

\section{CONCLUSIONS}

This study evaluated the ability of various combinations of polyunsaturated oils (safflower or flaxseed) with monensin and/or vitamin $\mathrm{E}$ to increase the concentration of CLA in bovine milk. The experiments demonstrated that a combination of safflower oil with monensin was effective at increasing milk fat CLA and that the effect of monensin was consistent over a period of 2 mo. The addition of vitamin $\mathrm{E}$ to the diet partially prevented the depression in milk fat associated with the addition of oils to the dairy diet. It also decreased the level of total trans 18:1 in milk, although there was no reduction in milk CLA. The flaxseed and vitamin $\mathrm{E}$ combination also increased milk CLA concentrations compared with the control. In addition to the increase in CLA, diets including safflower or flaxseed oil resulted in other favorable changes in the FA profile such as a decrease in 14:0 and 16:0.

These studies clearly demonstrate the possibility for sustainable production of milk with levels of CLA up to 10 times higher than typical levels in dairy fat. The manufacture of CLA-enriched milk and milk products could supply dietary CLA at levels that may benefit health, without the need for unrealistic changes to eating habits.

\section{ACKNOWLEDGMENTS}

The authors thank the Alberta Agricultural Research Institute, Alberta Milk, Dairy Farmers of Canada, and the Natural Sciences and Engineering Research Council of Canada for financial assistance for this research. 
We appreciate the help of the Dairy Research and Technology Centre staff, especially Harold Lehman and Pavol Zalkovic, for the feeding and care of the experimental animals; the help of fellow researchers and graduate students in sample collection; and the assistance of Pat Marceau in feed analysis. The authors also thank Laki Goonewardene for assistance with statistical analysis.

\section{REFERENCES}

AbuGhazaleh, A. A., D. J. Schingoethe, A. R. Hippen, and K. F. Kalscheur. 2004. Conjugated linoleic acid increases in milk when cows fed fish meal and extruded soybeans for an extended period of time. J. Dairy Sci. 87:1758-1766.

AOAC. 1996. Official Methods of Analysis. Association of Official Analytical Chemists, Gaithersburg, MD.

Bauman, D. E., D. M. Barbano, D. A. Dwyer, and J. M. Griinari. 2000. Production of butter with enhanced conjugated linoleic acid for use in biomedical studies with animal models. J. Dairy Sci. 83:2422-2425

Baumgard, L. H., B. A. Corl, D. A. Dwyer, A. Sæbø, and D. E. Bauman. 2000. Identification of the conjugated linoleic acid isomer that inhibits milk fat synthesis. Am. J. Physiol. 278:R179-R184.

Bauman, D. E., and J. M. Griinari. 2001. Regulation and nutritional regulation of milk fat: Low-fat milk syndrome. Livest. Prod. Sci. 70:15-29.

Berner, L. A. 1993. Roundtable discussion on milkfat, dairy foods, and coronary heart disease risk. J. Nutr. 123:1175-1184

Brubacher, G., W. Müller-Muot, and D. A. T. Southgate. 1985. Vitamin E (only $\alpha$-tocopherol) in foodstuffs: HPLC method. Pages 97-106 in Methods for the Determination of Vitamins in Food. Elsevier Appl. Sci. Publ. Ltd., London, UK.

Campbell, W., M. A. Drake, and D. K. Larick. 2003. The impact of fortification with conjugated linoleic acid (CLA) on the quality of fluid milk. J. Dairy Sci. 86:43-51.

Charmley, E., and J. W. G. Nicholson. 1993. Injectable $\alpha$-tocopherol for control of oxidized flavour in milk from dairy cows. Can. J. Anim. Sci. 73:381-392.

Charmley, E., and J. W. G. Nicholson. 1994. Influence of dietary fat source on oxidative stability and fatty acid composition of milk from cows receiving a low or high level of dietary vitamin E. Can. J. Anim. Sci. 74:657-664.

Chilliard, Y., A. Ferlay, R. M. Mansbridge, and M. Doreau. 2000. Ruminant milk fat plasticity: Nutritional control of saturated, polyunsaturated, trans and conjugated fatty acids. Ann. Zootech. (Paris) 49:181-205.

Chilliard, Y., A. Ferlay, J. Rouel, and G. Lamberett. 2003. A review of nutritional and physiological factors affecting goat milk lipid synthesis and lipolysis. J. Dairy Sci. 86:1751-1770.

Chin, S. F., W. Liu, J. M. Storkson, Y. L. Ha, and M. W. Pariza. 1992. Dietary sources of conjugated dienoic isomers of linoleic acid, a newly recognized class of anticarcinogens. J. Food Comp. Anal. 5:185-197.

Chouinard, P. Y., L. Corneau, W. R. Butler, Y. Chilliard, J. K. Drackley, and D. E. Bauman. 2001. Effect of dietary lipid source on conjugated linoleic acid concentrations in milk fat. J. Dairy Sci. 84:680-690.

Chouinard, P. Y., L. Corneau, L. M. Kelly, J. M. Griinari, and D. E. Bauman. 1998. Effect of dietary manipulation on milk conjugated linoleic acid concentrations. J. Dairy Sci. 81(Suppl.1):233. (Abstr.)

Chouinard, P. Y., L. Corneau, A. Sæbø, and D. E. Bauman. 1999. Milk yield and composition during abomasal infusion of conjugated linoleic acids in dairy cows. J. Dairy Sci. 82:2737-2745.

Christie, W. W. 1982. A simple procedure for transmethylation of glycerolipids and cholesterol esters. J. Lipid Res. 23:1073-1075.

Dhiman, T. R., G. R. Anand, L. D. Satter, and M. W. Pariza. 1999. Conjugated linoleic acid content of milk from cows fed different diets. J. Dairy Sci. 82:2146-2156.
Dhiman, T. R., L. D. Satter, M. W. Pariza, M. P. Galli, K. Albright, and M. X. Tolosa. 2000. Conjugated linoleic acid (CLA) content from cows offered diets rich in linoleic and linolenic acid. J. Dairy Sci. 83:1016-1027.

Doreau, M., and A. Ferlay. 1994. Digestion and utilization of fatty acids by ruminants. Anim. Feed Sci. Technol. 45:379-396.

Elliot, J. P., J. K. Drackley, A. D. Beaulieu, C. G. Aldrich, and N. R. Merchen. 1999. Effects of saturation and esterification of fat sources on site and extent of digestion in steers: Digestion of fatty acids, triglycerides, and energy. J. Dairy Sci. 77:1919-1929.

Fellner, V., F. D. Sauer, and J. K. G. Kramer. 1997. Effect of nigericin, monensin and tetronasin on biohydrogenation in continuous flowthrough ruminal fermenters. J. Dairy Sci. 78:1815-1823.

Focant, M., E. Mignolet, M. Marique, F. Clabots, T. Breyne, D. Dalemans, and Y. Larondelle. 1998. The effect of vitamin E supplementation of cow diets containing rapeseed and linseed on the prevention of milk fat oxidation. J. Dairy Sci. 81:1095-1101.

Folch, J., M. Lees, and G. H. S. Stanley. 1957. A simple method for the isolation and purification of total lipids from animal tissues. J. Biol. Chem. 226:477-480.

Gaynor, P. J., D. R. Waldo, A. V. Capuco, R. A. Erdman, L. W. Douglass, and B. B. Teter. 1995. Milk fat depression, the glucogenic theory and trans-C18:1 fatty acids. J. Dairy Sci. 78:2008-2015.

Griinari, J. M., and D. E. Bauman. 1999. Biosynthesis of conjugated linoleic acid and its incorporation into meat and milk of ruminants. Pages 180-200 in Advances in Conjugated Linoleic Acid Research, Vol. 1. M. P. Yurawecz, M. M. Mossoba, J. K. G. Kramer, M. W. Pariza, and G. J. Nelson, ed. AOCS Press, Champaign, IL. Griinari, J. M., B. A. Corl, S. H. Lacy, P. Y. Chouinard, K. V. V. Nurmela, and D. E. Bauman. 2000. Conjugated linoleic acid is synthesized endogenously in lactating cows by $\Delta-9$ desaturase. J. Nutr. 130:2285-2291.

Griinari, J. M., D. A. Dwyer, M. A. McGuire, D. E. Bauman, D. L. Palmquist, and K. V. V. Nurmela. 1998. Trans-octadecanoic acids and milk fat depression in lactating dairy cows. J. Dairy Sci. 81:1251-1261.

Hidiroglou, M. 1989. Mammary transfer of vitamin E in dairy cows. J. Dairy Sci. 72:1067-1071.

Ip, C., M. Singh, H. J. Thompson, and J. M. Scimeca. 1994. Conjugated linoleic acid suppresses carcinogenesis and proliferative activity of the mammary gland in the rat. Cancer Res. 54:1212-1215.

Jenkins, T. C., V. Fellner, and R. K. McGuffey. 2003. Monensin by fat interactions on trans fatty acids in cultures of mixed ruminal microorganisms grown in continuous fermenters fed corn or barley. J. Dairy Sci. 86:324-330.

Jensen, S. K., and K. N. Nielsen. 1996. Tocopherols, retinol, $\beta$-carotene and fatty acids in fat globule membrane and fat globule core in cow's milk. J. Dairy Res. 63:565-574.

Kalscheur, K. F., B. B. Teter, L. S. Piperova, and R. A. Erdman. 1997. Effect of fat source on duodenal flow of trans-C18.1 fatty acids and milk fat production in dairy cows. J. Dairy Sci. 80:2115-2126.

Kay, J. K., T. R. Mackle, M. J. Auldist, N. A. Thomson, and D. E. Bauman. 2004. Endogenous synthesis of cis-9, trans-11 conjugated linoleic acid in dairy cows fed fresh pasture. J. Dairy Sci. 87:369-378.

Kay, J. K., J. R. Roche, E. S. Kolver, N. A. Thomson, and L. H. Baumgard. 2005. A comparison between feeding systems (pasture and TMR) and the effect of vitamin E supplementation on plasma and milk fatty acid profiles in dairy cows. J. Dairy Res. 72:322-332

Kelly, M. L., J. R. Berry, D. A. Dwyer, J. M. Griinari, P. Y. Chouinard, M. E. Van Amburgh, and D. E. Bauman. 1998. Dietary fatty acid sources affect conjugated linoleic acid concentrations in milk from lactating dairy cows. J. Nutr. 128:881-885.

Kepler, C. R., K. P. Hiron, J. J. McNeill, and S. B. Tove. 1966. Intermediates and products of the biohydrogenation of linoleic acid by Butyrivibrio fibrisolvens. J. Biol. Chem. 241:1350-1354.

Larondelle, Y., M. Focant, E. Mignolet, and J. M. Griinari. 2002. Method to alter the isomeric profile of trans fatty acids in ruminant meat and milk and to increase the concentration of cis-9, trans-11 conjugated linoleic acid. PCT application, number WO 02/05 1255 . 
Lawless, F., J. J. Murphy, D. Harrington, R. Devery, and C. Stanton. 1998. Elevation of conjugated cis-9, trans-11-octadecadienoic acids in bovine milk because of dietary supplementation. J. Dairy Sci. 81:3259-3267.

Ma, D. W. L., J. G. Ens, C. J. Field, and M. T. Clandinan. 2000. Conjugated linoleic acid: Methods, biological effects and mechanisms. Res. Adv. Oil Chem. 1:79-101.

Mensink, R. P., and M. B. Katan. 1990. Effect of dietary trans fatty acids on high-density and low-density lipoprotein cholesterol in healthy subjects. N. Engl. J. Med. 23:439-445.

National Research Council. 1989. Nutritional Requirements of Dairy Cattle. 6th rev. ed. Natl. Acad. Sci., Washington, DC.

Noakes, M., P. J. Nestel, and P. M. Clifton. 1996. Modifying the fatty acid profile of dairy products through feedlot technology lowers plasma cholesterol of humans consuming the products. Am. J. Clin. Nutr. 63:42-46.

Offer, N. W., M. Marsden, J. Dixon, B. K. Speake, and F. F. Thacker. 1999. Effect of dietary fat supplements on levels of n-3 polyunsaturated fatty acids, trans fatty acids and conjugated linoleic acid in bovine milk. Anim. Sci. 69:613-625.

Palmquist, D. L., and J. M. Griinari. 2001. Dietary fish oil plus vegetable oil maximizes trans-18:1 and rumenic acids in milk fat. J. Dairy Sci. 84(Suppl.1):310. (Abstr.)

Pariza, M. W., and W. A. Hargraves. 1985. A beef-derived mutagenesis modulator inhibits initiation of mouse epidermal tumors by 7,12-dimethylbenz[a]anthrazene. Carcinogensis 6:591-593.

Parodi, P. W. 1999. Conjugated linoleic acid: The early years. Pages 1-11 in Advances in Conjugated Linoleic Acid Research, Vol. 1. M. P. Yurawecz, M. M. Mossoba, J. K. G. Kramer, M. W. Pariza, and G. J. Nelson, ed. AOCS Press, Champaign, IL.

Peterson, D. G., E. A. Matitashvili, and D. E. Bauman. 2003. Dietinduced milk fat depression in dairy cows results in increased trans-10, cis-12 CLA in milk fat and coordinate suppression of mRNA abundance for mammary enzymes involved in milk fat synthesis. J. Nutr. 133:3098-3102.

Piperova, L. S., B. B. Teter, I. Bruckental, J. Sampugna, S. E. Mills, M. P. Yurawecz, J. Fritsche, K. Ku, and R. A. Erdman. 2000.
Mammary lipogenic enzyme activity, trans fatty acids and conjugated linoleic acids are altered in lactating dairy cows fed a milk fat-depressing diet. J. Nutr. 130:2568-2574.

Precht, D., and D. Molkentin. 1997. Trans-geometrical and positional isomers of linoleic acid including conjugated linoleic acid (CLA) in German milk and vegetable fats. Fett Lipid 99:319-326.

Precht, D., D. Molkentin, F. Destaillats, and R. L. Wolff. 2001. Comparative studies on individual 18:1 isomeric acids in cow, goat, and ewe milk fats by low-temperature high-resolution capillary gas-liquid chromatography. Lipids 36:827-832.

Ramanzin, R., L. Bailoni, S. Schiavon, and G. Bittante. 1997. Effect of monensin on milk production and efficiency of dairy cows fed two diets differing in forage to concentrate ratios. J. Dairy Sci. 80:1136-1142.

Ritzenthaler, K. L., M. K. McGuire, R. Falen, T. D. Shultz, N. Dasgupta, and M. A. McGuire. 2001. Estimation of conjugated linoleic acid intake by written dietary assessment methodologies underestimates actual intake evaluated by food duplicate methodology. J. Nutr. 131:1548-1554.

SAS User's Guide: Statistics, Version 8.3. SAS Inst., Inc., Cary, NC. Sauer, F. D., V. Fellner, R. Kinsman, J. K. G. Kramer, H. A. Jackson, A. J. Lee, and S. Chen. 1998. Methane output and lactation response in Holstein cattle with monensin or unsaturated fat added to the diet. J. Anim. Sci. 76:906-914.

Solomon, R., L. E. Chase, D. Ben-Ghedalia, and D. E. Bauman. 2000. The effect of nonstructural carbohydrate and addition of full fat extruded soybeans on the concentration of conjugated linoleic acid in the milk fat of dairy cows. J. Dairy Sci. 83:1322-1329.

Turpeinen, A. M., M. Mutanen, A. Aro, I. Salminen, S. Basu, D. L. Palmquist, and J. M. Griinari. 2002. Bioconversion of vaccenic acid to conjugated linoleic acid in humans. Am. J. Clin. Nutr. 76:504-510.

Ulberth, F., and M. Henninger. 1994. Quantitation of trans fatty acids in milk fat using spectroscopic and chromatographic methods. J. Dairy Res. 61:517-527.

Van Soest, P. J., J. B. Robertson, and B. A. Lewis. 1991. Methods for fibre, neutral detergent fibre and nonstarch polysaccharides in relation to animal nutrition. J. Dairy Sci. 74:3583-3597. 